\title{
Talajminták lézeres szemcseanalízisének módszertani tapasztalatai
}

\author{
${ }^{1}$ MAKó András, ${ }^{1,2}$ VARGA Tamás, ${ }^{1,3}$ HeRNÁDI Hilda, \\ ${ }^{4}$ LABANCZ Viktória, ${ }^{1}$ BARNA Gyöngyi \\ ${ }^{1}$ Magyar Tudományos Akadémia, Agrártudományi Kutatóközpont, Talajtani és Agro- \\ kémiai Intézet, Budapest \\ ${ }^{2}$ Pécsi Tudományegyetem, Természettudományi Kar, Földrajzi Intézet, Természet- és \\ Környezetföldrajzi Tanszék, Pécs \\ ${ }^{3}$ Pannon Egyetem, Georgikon Kar, Növénytermesztéstani és Talajtani Tanszék, \\ Keszthely \\ ${ }^{4}$ Szent István Egyetem, Mezőgazdaság-és Környezettudományi Kar, \\ Környezettudományi Intézet, Talajtani és Agrokémiai Tanszék, Gödöllő
}

\section{A talajok mechanikai összetételének vizsgálata}

A talaj szilárd fázisa általában különböző méretű és alakú szerkezeti elemekből (aggregátumokból) áll. A szerkezeti elemeket ugyancsak változatos méretü és formájú, a talajképző kőzettől ,átörökölt” vagy a talajképződés során helyben képződött ásványszemcsék, más néven elemi részecskék építik fel. Az elemi részecskéket az aggregátumokban élő és elhalt szerves anyagok és egyéb kolloid méretü ragasztóanyagok tartják össze. Az elemi részecskék méret szerinti százalékos megoszlását nevezzük a talajok mechanikai összetételének (a továbbiakban MÖ). A talajok MÖ vizsgálati eredményei széles körben felhasználhatóak. A talajosztályozási, vagy a geomorfológiai kutatások (üledék-képződési és hordalékszállítási folyamatok értelmezése) során sokszor elengedhetetlen az egyes genetikai szintekben, illetve rétegekben a MÖ ismerete (pl. TÓTH et al., 2009; KURÁž et al., 2012). A szilárd fázist alkotó elemi részecskék mérete a talajok több tulajdonságát befolyásolja; elsősorban meghatározza a talajok fajlagos felületét, és ezen keresztül a határfelületeken lejátszódó legfontosabb talajfizikai és -kémiai jelenségeket (pl. kapillaritás, ion- és molekula-adszorpció). A MÖ hatással van a talajok pórusméret-eloszlására, víztartó- és vízvezető-képességére (WÖSTEN et al., 2001; HAJNOS et al., 2006; TóTH et al., 2015), a nem vizes fázisú folyadékokra (Nonaqueous Phase Liquids: NAPLs) vonatkozó folyadéktartó és folyadékvezető képességére (BUDHU et al., 1991; WEAVER et al., 1994). Befolyásolja továbbá a talajok légáteresztő képeségét (HАMАмото et al., 2009), hővezető képességét (USOWICZ et al., 2008), reológiai tulajdonságait (CZIBULYA et al., 2010; SHEIN et al., 2011) és szorpciós tulajdonságaikat (TOMBÁCZ, 2002; ERTLI et al., 2004). A talajok mikrobiális aktivitása (BRZEZIÑSKA et al., 2012) vagy a talajok szerkezetessége (BALASHOV et al., 2010) szintén függ a MÖ-től. A MÖ adatokból számíthatók egyéb talajjellemzők, mint pl. a talajok fraktáldimenziója is (BIEGANOWSKI et al., 2013).

Postai cím: MAKÓ ANDRÁS, Magyar Tudományos Akadémia Agrártudományi Kutatóközpont. Talajtani és Agrokémiai Intézet, 1022 Budapest, Herman Ottó út 15.

E-mail: mako_andras@ rissac.hu 
A fentiek miatt a talajok MÖ vizsgálati eredményeit a hidrológiában, illetve a talajfizikában gyakran felhasználják becslő eljárásokban, bemenő (input) paraméterként. Így a MÖ az egyik legfontosabb talajjellemzö a vízvisszatartó-, illetve vízvezetö-képességet becslö ún. „pedotranszfer függvényekben” (pl. RAJKAI, 1988; BOUMA, 1989; RAJKAI et al., 1996). A talajokat szennyező apoláros szerves folyadékok (pl. kőolajszármazékok) önálló fázisú vagy a szennyező komponensek többfázisú terjedésének modellezésekor a talaj szervesfolyadék-visszatartó és szervesfolyadék-vezető képességét is sok esetben a MÖ adatok, vagy a fizikai féleség kategóriák alapján becslik a kárelhárítással foglalkozó szakemberek (DRAGUN, 1998).

A MÖ vizsgálatok során alkalmazott mérettartományokat a gyakorlati tapasztalatok alapján alakították ki, mégis országonként, sőt szakterületenként eltérő határértékeket használnak az egyes frakciók elkülönítésére. A szakterületenként kialakított és elfogadott mérési módszerek is különbözőek lehetnek. A különböző módszerekkel kapott eredmények eltérhetnek egymástól, attól függően, hogy pl. milyen előkészítési módot és/vagy a frakciók elkülönítéséhez milyen mérőeszközt alkalmazunk. Mivel a talajok mechanikai összetételének meghatározása - a fentiek alapján - több tudományterület egyik leggyakrabban elvégzett rutin vizsgálata, egyre inkább szükségessé válik olyan mérési módszerek szabványosítása, amely az egyes szakterületek számára elfogadható, a mérések egyszerüen elvégezhetőek és minél inkább automatizálhatóak. Fontos feladat lenne továbbá a már meglévő, a különféle szemcseméret-osztályozási rendszerek, mérési módszerek stb. alapján meghatározott mechanikai összetétel adatok egységes adatbázisba szervezése és összehasonlíthatóságuk megteremtése (NEMES et al., 1999).

A MÖ vizsgálata során a mérés legfontosabb szakaszai: a talajaggregátumok roncsolása elemi alkotóelemekké, az elemi szemcsék tartós diszpergálása és a diszpergált részek méret szerinti elkülönítése.

A talajok aggregáltsága miatt a mechanikai összetétel mérésénél általában kulcsfontosságú a minták előkészítése (roncsolása és diszpergálása). A talajok kötöanyagként általában szerves anyagokat, vasoxidokat és karbonátokat tartalmaznak. A kémiai előkezelés különböző szakaszainak célja részben az, hogy ezeket a ragasztóanyagokat eltávolítsuk (GEE \& BAUDER, 1986). Ugyanakkor a tapasztalat azt mutatja, hogy a kémiai előkezeléssel bizonyos talajásványokat is elroncsolhatunk, illetve kioldhatunk a talajból (MAKó et al., 2002; BALÁZS et al., 2011; GOOSSENS et al., 2014; SCHULTE et al., 2016). A kémiai előkezelések során további cél az - aggregátumokból felszabadított - elemi részecskék diszpergálása a negatív töltésü adszorpciós helyek nagy elektronegativítású kationokkal (alkálifém kationok, általában $\mathrm{Na}^{+}$vagy $\mathrm{Li}^{+}$) történő telítésével. Az adszorbeált alkálifém ionok nagy hidrátburkuk segítségével megakadályozzák a részecskék újbóli összetapadását.

A kémiai diszpergáláson túl a mechanikai diszpergálás (a talajszuszpenzió különböző ideig történő rázatása vagy keverése különböző típusú eszközökkel) a legggyakrabban alkalmazott rutin módszer a laboratóriumokban. Az ultrahangos diszpergálás a lézerdiffrakciós méréseknél általánosan elterjedt, míg az ülepítéses módszerek esetében többnyire csak módszertani kutatások során találkozunk vele (GENRICH \& BREMNER, 1972). A MÖ vizsgálatok során egyértelműen jelezni kell, 
hogy mely módszerrel, mely vizsgálati szabvány alkalmazásával, milyen előkészítések mellett végeztük a méréseket, hiszen a tapasztalatok azt mutatják, hogy azonos mérési módszer alkalmazása mellett is eltérő eredményeket kapunk, ha különböző előkészítési módokat alkalmazunk (McKEAUGE, 1978). (A legszélesebb körben használt ISO 11277: 2009(E) nemzetközi szabvány esetében pl. a szerves anyagok roncsolása, valamint a gipsz és az oldható sók eltávolítása kötelezően elöírt előkészítő lépés, azonban a karbonátok és a vas-oxidok eltávolítása opcionális lehetőség, a laborvezetô helyi döntésétől függ.)

A MÖ vizsgálatok során a homok szemcseméret-tartományba eső részecskéket általában szitálással választják el egymástól. A homokfrakciónál kisebb méretü részecskék mennyiségét leggyakrabban ülepítéses eljárásokkal határozzuk meg (GEE \& BAUDER, 1986). Az ülepítéses módszereket - megfigyelések alapján - már az 1700-as évek elejétől használták a különböző méretü talajrészecskék elválasztására (MILLER et al., 1988), míg a Stokes-törvény alkalmazása a 1904-től ismert (HALL, 1904). Az ülepítéses módszerek elméleti alapjául szolgáló Stokes-törvény a gömbszerünek feltételezett talajszemcsék ún. „ekvivalens átméröje” alapján számítja az ülepedési sebességet (VÁRALLYAY, 1993). A módszerek alkalmazása során ez hibák forrása lehet, hiszen az elemi részecskék többnyire szabálytalan alakúak (az agyag mérettartomány felé haladva egyre inkább lemezes vagy csöves formájúak) (CLIFTON et al., 1999). A különböző alakú, de azonos ekvivalens átmérőjünek tekintett szemcsék ülepedési sebessége nem állandó, bár a módszer annak tekinti. Befolyásolhatja az ülepedési sebességet a szemcsék eltérő sűrüsége is (MATTHEws, 1991). E módszerek további hátránya, hogy relatív nagy mintatömeget igényelnek (20-40 g), időigényesek (különösen a $2 \mu \mathrm{m}$-nél kisebb méretủ frakció esetében) és a legtöbb esetben korlátozott felbontásban képesek megadni az egyes mérettartományokba eső anyagmennyiségeket. Mindezeken túl az $1 \mu \mathrm{m}$-nél kisebb méretü részecskék mennyisége a csökkenő részecskemérettel arányosan növekvő bizonytalansággal mérhető az ülepedési sebességet befolyásoló Brown-féle mozgás következtében (LOVELAND \& WHALLEY, 2001). A talaj MÖ vizsgálatok céljára leginkább két - a Stokes-törvényen alapuló - vizsgálati módszer terjedt el. A pipettás módszerrel az ülepedő szuszpenzió tömegszázalékos koncentrációját, a hidrométeres módszerrel a sürüségét határozzuk meg. A vizsgálati módszereket szakterületenként különféle nemzeti és nemzetközi szabványok rögzítik (pl. MSZ08 0205-78; ALLEN, 1990; LU et al., 2000; VAN REEUWIJK, 2002; ISO 11277:2009(E)). A pipettás és hidrométeres módszerrel mért eredmények azonos előkészítési módot alkalmazva közel hasonlóak (LIU et al., 1966; GoOSSENS, 2008). Bár a hidrométeres módszerek a pipettás mérésekhez képest már lényegesen egyszerübbek, azért még mindig idö- és munkaigényesek. Az ülepítéses módszerek további hátránya, hogy a legtöbb esetben a részecskeméret-eloszlás (,,szemeloszlás") görbének csupán néhány (általában az egyes frakciók mérethatárainak megfelelö) pontját határozzák meg. Az ülepítésen alapuló további - a talajok MÖ-ének meghatározására kevésbé elterjedt - mérési elárás az Atterberg-féle iszapolás (DI GLÉRIA et al., 1957), a centrifugás módszer (JACKSON, 1958) vagy a fotoszedimentációs módszer (BUAH-BASSUAH et al., 1998). 
Újra és újra felmevetődik a különböző ipari alapanyagok szemcseeloszlás meghatározására használt müszeres mérési módszerek (optikai vagy scanning elektron mikroszkópok, röntgensugár gyengítéses módszer, az ún. Coulter részecskeszámláló módszer vagy a fényszórás fotometria vizsgálatok) talajtani alkalmazhatóságának lehetősége. Ezek közül az eljárások közül a lézerdiffrakción alapuló módszertant az 1970-es években fejlesztették ki (ALLEN, 1990; MA et al., 2000) és jó eredménnyel adaptálták különbözö üledékek vizsgálatára (KONERT \& VANDENBERGHE, 1997; KENKILÄ, 2005; RAMASWAMI \& RAO, 2006).

Egyre több esetben felmerül a kérdés, hogy mely mérési, illetve előkészítési módszer tekinthető jónak, elfogadhatónak. A kérdés megválaszolásához hozzásegíthet bennünket, ha a mechanikai összetétel mérési eredményeket összevetjük olyan egyéb, azonos mintaállományon meghatározott talajfizikai paraméterekkel, melyek kapcsolata egyébként a MÖ eredményekkel (pl. az agyagtartalom százalékos mennyiségével) tudományosan igazolt. Ilyen talajparaméterek lehetnek pl. a talaj fajlagos felülete, adszorpciós képessége, képlékenységi mutatói stb. (MAKó et al., 2002; MAKÓ \& HERNÁDI, 2010).

\section{A talajok mechanikai összetételének meghatározása lézerdiffrakciós módszerrel}

Az optikai mérési módszerek elterjedése áttörést jelentett számos tudományterületen. A lézeres eszközökön alapuló mérések pontossága forradalmasította a mérési módszereket, új irányvonalakat jelölt ki mind a módszertani szemléletben, mind a müszergyártásban. Sokoldalúságának köszönhetően a lézer alkalmas többek között távolság és sebesség mérésére, ellipszometriai vizsgálatok elvégzésére, valamint a fény szóródásán alapuló aeroszol vagy hidroszol koncentráció mérésére. Sokoldalú alkalmazhatósága miatt a talajtani anyagvizsgálatban is egyre nagyobb szerepet kap (GEE \& BAUDER, 1986).

A lézerdiffrakciós módszert (LDM) egyre többen alkalmazzák a talaj MÖ-ének meghatározására (MCCAVE et al., 1986; BUURMAN et al., 1997; BEUSELINCK et al., 1998; Pye \& BlotT, 2004; BLOTT \& PYE, 2006; RYŻAK \& BIEGANOWSKI, 2011; SOCHAN et al., 2012; FENTON et al., 2015; SERBAN et al., 2015; YANG et al., 2015). Az LDM elméleti alapja az, hogy a készülékbe adagolt, megfelelő koncentrációjú talajszuszpenziót monokromatikus lézersugárnyaláb világítja át és a részecskék által többféle szögben szórt fényt egy több elemből álló detektor érzékeli (BÜRKHOLZ \& POLKE, 1984). A detektorok által rögzített diffrakciós kép-adatokat a választott optikai modell (ld. később) segítségével transzformálják, a teljes térfogat részeit diszkrét számú méretosztályba sorolják, majd az eredményt térfogati részecskeméret-eloszlásként adják meg (DE BOER et al., 1987; ALLEN, 1990). Gömbszerü és egyforma sürüségü elemi részecskéket feltételezve a mért térfogatarányos szemcseméret-eloszlás megegyezik a tömegarányossal (BIEGANOWSKI et al., 2012).

A módszer elónye a gyorsasága (max. 3-10 perc/minta) mellett, hogy a mérési eredményt egy folytonos függvényként adja meg, így az eredmények könnyebben összevethetők különböző szemcseméret osztályozási rendszerek és mérési módszerek MÖ adataival. Emellett az eredmények jól reprodukálhatók (a különbözö egyéb mérési módszerekhez képest legalább egy nagyságrenddel pontosabbak) 
(ROBERSON \& WeLTJE, 2014; WANG et al., 2015). Az újabb lézerdiffrakciós elvü készülékek már a talajvizsgálatoknál megkívánt széles (tized mikrontól néhány milliméterig terjedő mérettartományban) képesek mérni. Az LDM mérések legfőbb hátránya (a műszerek viszonylagos drágasága mellett), hogy - többek között a talajfizikai mérésekre vonatkozó szabványosított módszer hiánya miatt - nem áll rendelkezésünkre kellő mennyiségủ tapasztalat a különböző hagyományos mérési módszerekkel kapott eredményekkel való összehasonlíthatóságról, átszámíthatóságról (RYŻAK \& BIEGANOWSKI, 2011). A viszonylag kis vizsgálandó mintamennyiség $(0,3-0,5 \mathrm{~g})$ sok esetben előnyös lehet (ritka, kis mennyiségben begyüjthető mintáknál). Hátránya viszont, hogy a kis bemért mintamennyiségek miatt felmerülhet a vizsgált részminták reprezentatívitásának kérdése. MILLER és SCHAETZL (2012) arról számoltak be, hogy a mintegy 1500 talajminta vizsgálata során a minták 11,5 \%-ának megváltozott a fizikai félesége a második részmintából történt mérések eredményei alapján.

Tanulmányunk összeállítása során legfőbb célkitüzésünk az volt, hogy áttekintsük azokat a LDM MÖ vizsgálatokkal foglalkozó - talajtani vonatkozású - közleményeket, melyek módszertani leírásokat, illetve javaslatokat tartalmaznak (1. táblázat). Ezek segíthetnek eligazodni az LDM MÖ mérések szerteágazó módszerei közt és - reményeink szerint - támpontot nyújthatnak egy majdani egységes vizsgálati módszertan kialakításához. Áttekintjük az alkalmazott fontosabb előkészítési eljárásokat, müszerbeállításokat, a hagyományos MÖ mérési módszerek eredményeivel történő megfeleltetés lehetőségeit. Végezetül rövid áttekintést adunk az LDM MÖ mérési módszer aggregátum-stabilitás vizsgálatokra történő alkalmazási lehetőségeiről is.

\section{A lézerdiffrakciós mérések eredményeit befolyásoló tényezők}

A szakirodalmi közlések szerint számos tényező befolyásolhatja a LDM MÖ mérések eredményeit.

A LDM nem képes különbséget tenni az elemi részecskéken és a talajaggregátumokon bekövetkező fényelhajlás között, ezért - hasonlóan az ülepítéses vizsgálatokhoz - döntő, hogy az elemi részecskék a mérés előtt dezaggregált, diszpergált állapotban legyenek. Emiatt a mérési eredmények alakulása nagymértékben függ az elókészitési módszer megválasztásától: a minták dezaggregálására és diszpergálására alkalmazott kémiai előkezelések (aggregátumokat összetartó ragasztóanyagok roncsolása, diszpergálószerek használata) alkalmazásától, a mechanikai diszpergálás intenzitásának és idejének beállításától (ARRIAGA et al., 2006; BIEGANOWSKI et al., 2010; RYŻAK \& BIEGANOWSKI, 2010; 2011; VDOviĆ et al., 2010; SOCHAN et al., 2012; 2014; SERBAN et al., 2015). A kémiai előkezelések során (pl. humuszroncsolás, vas-oxidok eltávolítása) megváltozhat a szuszpenzió színe, ami szintén befolyásolhatja a mérési eredményeket (EsHEL et al., 2004). 
1a. táblázat

Talajtani vonatkozású lézerdiffrakciós mechanikai összetétel vizsgálatok a szakirodalomban - készülék típusonként és előkészítő egységenként rendszerezve

\begin{tabular}{|c|c|c|c|c|}
\hline $\begin{array}{c}(1) \\
\text { Készülék } \\
\text { típusa } \\
\end{array}$ & \begin{tabular}{|c|}
$\begin{array}{c}(2) \\
\text { Elökészítő } \\
\text { egység }\end{array}$ \\
\end{tabular} & $\begin{array}{c}\text { (3) } \\
\begin{array}{l}\text { Vizsgált minta típusa } \\
\text { (mintaszám) }\end{array}\end{array}$ & $\begin{array}{c}(4) \\
\text { Irodalom }\end{array}$ & \begin{tabular}{|c|}
$(5)$ \\
Irodalom \\
kódja \\
\end{tabular} \\
\hline \multirow{2}{*}{$\begin{array}{l}\text { B.-Coulter } \\
\text { LS100 } \\
\& \\
\text { Malvern } \\
2600 \\
\end{array}$} & - & svájci folyami és tavi üledékek & LOIZEAU et al., 1994. & 1 \\
\hline & - & $\begin{array}{c}\text { belga agyagbemosódásos talajok, } \\
\text { kvarcminták (107) }\end{array}$ & BEUSELINCK et al., 1998. & 2 \\
\hline $\begin{array}{l}\text { B.-Coulter } \\
\text { LS120 }\end{array}$ & - & $\begin{array}{c}\text { spanyol talajmüvelési kísérletek } \\
\text { talajai (32) }\end{array}$ & $\begin{array}{l}\text { PAZ-FERREIRO et al., } \\
2010 . \\
\end{array}$ & 3 \\
\hline $\begin{array}{l}\text { B.-Coulter } \\
\text { LS130 }\end{array}$ & $\begin{array}{c}\text { Soniprep } \\
150\end{array}$ & Közép-angliai vízgyüjtő talajai (51) & WALLING et al., 2000. & 4 \\
\hline $\begin{array}{l}\text { B.-Coulter } \\
\text { LS200 }\end{array}$ & - & $\begin{array}{c}\text { belga különbözö textúrájú talajok } \\
(104)\end{array}$ & $\begin{array}{c}\text { VANDECASTEELE \& DE } \\
\text { Vos, } 2001 .\end{array}$ & 5 \\
\hline \multirow{6}{*}{$\begin{array}{l}\text { B.-Coulter } \\
\text { LS230 }\end{array}$} & - & brazil Oxisol talajok & BUURMAN et al., 1997. & 6 \\
\hline & - & $\begin{array}{c}\text { holland tengeri, fluviális és eolikus } \\
\text { üledékek (138) }\end{array}$ & BUURMAN et al., 2001. & 7 \\
\hline & - & $\begin{array}{c}\text { USA agyagos márgás üledékek } \\
(42)\end{array}$ & EsHEL et al., 2004. & 8 \\
\hline & - & $\begin{array}{l}\text { USA különbözö fel- és altalajok } \\
(43)\end{array}$ & Zовеск, 2004. & 9 \\
\hline & \begin{tabular}{|c|} 
nedves \\
előkészítő
\end{tabular} & $\begin{array}{l}\text { USA természetes és mesterséges } \\
\text { talajok (18) }\end{array}$ & ARRIAGA et al., 2006. & 10 \\
\hline & - & spanyol talajok (5) & GuZMÁN et al., 2010. & 11 \\
\hline \multirow{3}{*}{$\begin{array}{l}\text { B.-Coulter } \\
\text { LS-13 } 320\end{array}$} & - & kínai talajok (43) & WANG et al., 2013. & 12 \\
\hline & - & kínai talajok (1013) & WANG et al., 2015. & 13 \\
\hline & - & német és kínai talajok & SCHULTE et al., 2016. & 14 \\
\hline Micro Trac & - & USA talajok és üledékek (10) & COOPER et al., 1984. & 15 \\
\hline $\begin{array}{c}\text { MicroTrac } \\
\text { S3500 }\end{array}$ & - & indiai különböző talajok (50) & JENA et al., 2013. & 16 \\
\hline
\end{tabular}

A talajok LDM MÖ mérésére különféle eszközöket vehetünk igénybe $(1 a-1 c$. táblázat). A mérőműszerek detektorainak eltérö száma miatt változhat a MÖ mérések mérethatára és a szemeloszlási görbék mért pontjainak sűrüsége (BUURMAN et al., 1997; GoOSSENS, 2008).

Néhány tanulmányban a talajmintákat előzőleg $105{ }^{\circ} \mathrm{C}$-on kiszárították a MÖ mérések elött (pl. BITTELI et al., 1999; FERRO \& MiRABILE, 2009; VDOVIĆ et al, 2010); a legtöbb esetben légszáraz mintákat vizsgáltak (pl. RYŻAK \& BIEGANOWSKI, 2011; GoOSSENS et al., 2014; MAKÓ et al., 2014). Míg az ülepítéses MÖ talajvizsgálati módszerek esetében szabványok írják elő az előkészítés módját (ld. fentebb), a lézerdiffrakciós MÖ vizsgálatok esetében mindezidáig nem alkottak egységes talaj-előkészítési szabványokat. 


\section{1b. táblázat}

Talajtani vonatkozású lézerdiffrakciós mechanikai összetétel vizsgálatok a szakirodalomban - készülék típusonként és előkészítő egységenként rendszerezve

\begin{tabular}{|c|c|c|c|c|}
\hline $\begin{array}{c}(1) \\
\text { Készülék } \\
\text { típusa }\end{array}$ & \begin{tabular}{|c|}
$\begin{array}{c}(2) \\
\text { Előkészítő } \\
\text { egység }\end{array}$ \\
\end{tabular} & $\begin{array}{c}\text { (3) } \\
\begin{array}{c}\text { Vizsgált minta típusa } \\
\text { (mintaszám) }\end{array}\end{array}$ & $\begin{array}{c}(4) \\
\text { Irodalom }\end{array}$ & \begin{tabular}{|c|}
$(5)$ \\
Irodalom \\
kódja \\
\end{tabular} \\
\hline \multirow{5}{*}{$\begin{array}{c}\text { Fritsch } \\
\text { Analysette } \\
22\end{array}$} & - & $\begin{array}{c}\text { kvarc modellanyag (4) és holland } \\
\text { talajok (158) }\end{array}$ & \begin{tabular}{|c|} 
KONERT \& \\
VANDENBERGHE, 1997. \\
\end{tabular} & 17 \\
\hline & - & orosz csernozjom talajok (10) & SHEIN et al., 2006. & 18 \\
\hline & - & $\begin{array}{c}\text { orosz szology, csernozjom, podzol } \\
\text { talajok és talajkeverékek }\end{array}$ & FEDOTOv et al., 2007. & 19 \\
\hline & - & olasz talajok, A szint (40) & ANTINORO et al., 2012. & 20 \\
\hline & - & $\begin{array}{c}\text { magyar változatos textúrájú és } \\
\text { struktúrájú talajok (8) }\end{array}$ & CENTERI et al., 2015. & 21 \\
\hline $\begin{array}{c}\text { Fritsch } \\
\text { Analysette } \\
22 \\
\text { Compact } \\
\end{array}$ & - & $\begin{array}{c}\text { jellegzetes magyar és európai felta- } \\
\text { lajok (170) }\end{array}$ & HERNÁDI et al., 2008. & 22 \\
\hline \multirow{3}{*}{$\begin{array}{c}\text { Fritsch } \\
\text { Analysette } \\
22 \mathrm{ECO}\end{array}$} & - & $\begin{array}{l}\text { olasz különböző textúrájú talajok } \\
\qquad(30)\end{array}$ & $\begin{array}{l}\text { FERRO \& MIRABILE, } \\
2009 .\end{array}$ & 23 \\
\hline & - & olasz talajok (228) & Di STEFANO, 2010. & 24 \\
\hline & - & olasz talajok (747) & Di STEFANO, 2011. & 25 \\
\hline \multirow{3}{*}{$\begin{array}{c}\text { Fritsch } \\
\text { Analysette } \\
22 \\
\text { MicroTec }\end{array}$} & - & $\begin{array}{c}\text { magyar különbözö alapközeten } \\
\text { kialakult talajok (17) }\end{array}$ & MADARÁSZ et al., 2012. & 26 \\
\hline & - & magyar folyóvizi hordalék (25) & Kun et al., 2013. & 27 \\
\hline & - & $\begin{array}{c}\text { szlovák durva és közepesen finom } \\
\text { talajok (4) }\end{array}$ & $\begin{array}{l}\text { KONDRLOVA et al., } \\
2015 . \\
\end{array}$ & 28 \\
\hline $\begin{array}{l}\text { Horiba LA- } \\
920\end{array}$ & - & eltérő fizikai féleségü talajok (5) & \begin{tabular}{|l|} 
KOWALENKO \& BABUIN, \\
2013.
\end{tabular} & 29 \\
\hline $\begin{array}{c}\text { Horiba LA- } \\
930 \\
\end{array}$ & - & USA talajok (10) & SEGAL et al., 2009. & 30 \\
\hline $\begin{array}{l}\text { Malvern } \\
2600\end{array}$ & - & nigeri kavicsos márga (>200) & CHAPPELL, 1998. & 31 \\
\hline $\begin{array}{c}\text { Malvern } \\
3600 \mathrm{E}\end{array}$ & - & iszap & MCCAVE et al., 1986. & 32 \\
\hline $\begin{array}{l}\text { Mastersizer } \\
\text { Long-bed } \\
\text { X }\end{array}$ & MSX17 & litván tartamkísérletek talajai (92) & Bоотн et al., 2003. & 33 \\
\hline $\begin{array}{c}\text { Mastersizer } \\
\text { MS20 }\end{array}$ & - & USA és olasz talajok (8) & PIERI et al., 2006. & 34 \\
\hline
\end{tabular}




\section{1c. táblázat}

Talajtani vonatkozású lézerdiffrakciós mechanikai összetétel vizsgálatok a szakirodalomban - készülék típusonként és előkészítő egységenként rendszerezve

\begin{tabular}{|c|c|c|c|c|}
\hline $\begin{array}{c}(1) \\
\begin{array}{c}\text { Készïlék } \\
\text { típusa }\end{array} \\
\end{array}$ & \begin{tabular}{|c|}
$\begin{array}{c}(2) \\
\text { Elökészítő } \\
\text { egység }\end{array}$ \\
\end{tabular} & $\begin{array}{c}\text { (3) } \\
\begin{array}{c}\text { Vizsgált minta típusa } \\
\text { (mintaszám) }\end{array}\end{array}$ & $\begin{array}{c}(4) \\
\text { Irodalom }\end{array}$ & \begin{tabular}{|c|}
$(5)$ \\
Irodalom \\
kódja
\end{tabular} \\
\hline \multirow{24}{*}{$\begin{array}{c}\text { Mastersizer } \\
2000\end{array}$} & Hydro MU & $\begin{array}{c}\text { lengyel erdő-, réti és csernozjom } \\
\text { talajok (3) }\end{array}$ & BIEGANOWSKI et al., 2010. & 35 \\
\hline & Hydro MU & $\begin{array}{c}\text { lengyel réti, öntés és csernozjom } \\
\text { feltalajok (23) }\end{array}$ & $\begin{array}{l}\text { RYŻAK \& BIEGANOWSKI, } \\
2010 . \\
\end{array}$ & 36 \\
\hline & - & horvát réti és erdőtalajok (12) & VDOVIĆ et al., 2010. & 37 \\
\hline & Hydro G & finn és ausztrál rétegszilikátok (4) & GANTENBEIN et al., 2011. & 38 \\
\hline & Hydro MU & $\begin{array}{c}\text { lengyel réti, öntés és csernozjom } \\
\text { feltalajok (23) }\end{array}$ & $\begin{array}{l}\text { RYŻAK \& BIEGANOWSKI, } \\
2011 .\end{array}$ & 39 \\
\hline & Hydro MU & magyar talajok (4) & HERNÁDI et al., 2012. & 40 \\
\hline & Hydro MU & USA talajok (1485) & $\begin{array}{l}\text { MILLER \& SCHAETZL, } \\
2012 .\end{array}$ & 41 \\
\hline & \begin{tabular}{|c|} 
Hydro G \\
Hydro MU;
\end{tabular} & $\begin{array}{c}\text { lengyel réti, öntés és csernozjom } \\
\text { feltalajok (23) }\end{array}$ & SOCHAN et al., 2012. & 42 \\
\hline & Hydro G & $\begin{array}{c}\text { lengyel barna erdőtalaj A szintje } \\
\text { és lösz (2) }\end{array}$ & BIEGANOWSKI et al., 2013. & 43 \\
\hline & Hydro G & lengyel réti, váztalajok (84) & LAMORSKI et al., 2014. & 44 \\
\hline & Hydro G & $\begin{array}{c}\text { magyar réti, csernozjom, erdő és } \\
\text { szolonyec talajok (4) }\end{array}$ & MAKÓ et al., 2014. & 45 \\
\hline & Hydro MU & lengyel glaciális üledékek (20) & ORZECHOWSKI et al., 2014. & 46 \\
\hline & Hydro MU & $\begin{array}{c}\begin{array}{c}\text { kínai különböző fizikai féleségü } \\
\text { talajok (11) }\end{array} \\
\end{array}$ & PENG et al., 2015. & 47 \\
\hline & Hydro G & homokminták (3) & POLAKOWSKI et al., 2014. & 48 \\
\hline & Hydro MU & szennyvíziszap (2) & SOCHAN et al., 2014. & 49 \\
\hline & Hydro SM & magyar homok talaj (1) & Joó et al., 2015. & 50 \\
\hline & \begin{tabular}{|c|} 
Hydro G; \\
Hydro MU \\
\end{tabular} & üveggyöngyök- keveréksor & POLAKOWSKI et al., 2015. & 51 \\
\hline & Hydro MU & lengyel talajok (3) & SOCHAN et al., 2015. & 52 \\
\hline & - & kínai talajok (235) & YANG et al., 2015. & 53 \\
\hline & Hydro G & ír réti talajok (49) & FENTON et al., 2015. & 54 \\
\hline & Hydro G & magyar talajok (157) & MAKÓ et al., 2016b. & 55 \\
\hline & \begin{tabular}{|c|} 
Hydro G; \\
Hydro MU \\
\end{tabular} & magyar talajok (8) & MAKÓ et al., 2016a. & 56 \\
\hline & Hydro G & USA, homoktalajok (30) & $\begin{array}{c}\text { THOMAS \& REDSTEER, } \\
2016 .\end{array}$ & 57 \\
\hline & Hydro S & USA, sivatagi talajminták (96) & GoossEns et al., 2014 & 58 \\
\hline $\begin{array}{c}\text { Mastersizer } \\
3000\end{array}$ & Hydro LV & hullópor minták & VARGA et al., 2016. & 59 \\
\hline
\end{tabular}


2. táblázat

Az aggregátumok roncsolásának és a diszpergálás módszerének megválasztása a vizsgált közleményekben

\begin{tabular}{|c|c|c|c|c|}
\hline \multirow{2}{*}{$\begin{array}{c}\text { (1) } \\
\text { Roncsolás }\end{array}$} & \multirow{2}{*}{$\begin{array}{c}(2) \\
\text { Irodalom kódja }\end{array}$} & \multicolumn{2}{|c|}{$\begin{array}{c}\text { (3) } \\
\text { Ultrahangos } \\
\text { diszpergálás }\end{array}$} & \multirow{2}{*}{$\begin{array}{c}(2) \\
\text { Irodalom } \\
\text { kódja }\end{array}$} \\
\hline & & $\begin{array}{l}\text { UH időtar- } \\
\text { tama (min) }\end{array}$ & $\begin{array}{c}\text { UH } \\
\text { erössége }\end{array}$ & \\
\hline \multirow{3}{*}{$\begin{array}{c}\text { hidrogén-peroxid } \\
\text { (humusz eltávolí- } \\
\text { tás) }\end{array}$} & \multirow{3}{*}{$\begin{array}{c}2 ; 3 ; 4 ; 5 ; 6 ; 12 ; \\
13 ; 14 ; 15 ; 16 ; 17 ; \\
18 ; 22 ; 23 ; 24 ; 25 ; \\
26 ; 30 ; 33 ; 34 ; 37 ; \\
40 ; 45 ; 47 ; 50 ; 54 ; \\
57 ; 59\end{array}$} & 0,5 & $100 \%$ & 47 \\
\hline & & 0,5 & $35 \mathrm{~W}$ & 42 \\
\hline & & 0,5 & $\begin{array}{l}350 \mathrm{~W}, \\
20 \mathrm{kHz}\end{array}$ & 15 \\
\hline $\begin{array}{c}\mathrm{HCl} \\
\text { (mész eltávolítás) }\end{array}$ & $\begin{array}{c}14 ; 16 ; 17 ; 22 ; 40 ; \\
47 ; 59\end{array}$ & 1 & $\begin{array}{l}\text { energy } \\
\text { lvl. } 3\end{array}$ & 8 \\
\hline $\begin{array}{c}\text { Na-acetát } \\
\text { (mész eltávolítás) }\end{array}$ & $5 ; 34 ; 58$ & 1 & $50 \%$ & 38 \\
\hline \multirow{3}{*}{$\begin{array}{c}\text { Na-ditionit } \\
\text { (Fe-oxi-hidroxidok } \\
\text { eltávolítása) }\end{array}$} & \multirow{3}{*}{$6 ; 22 ; 40 ;$} & 1,5 & - & 9 \\
\hline & & 2 & - & $46 ; 54$ \\
\hline & & 3 & - & $\begin{array}{c}20 ; 23 ; 24 ; \\
25 ;\end{array}$ \\
\hline $\begin{array}{l}\text { (4) } \\
\begin{array}{c}\text { Kémiai diszpergá- } \\
\text { lószer }\end{array}\end{array}$ & $\begin{array}{c}(2) \\
\text { Irodalom kódja }\end{array}$ & 3 & $22 \mathrm{kHz}$ & 18 \\
\hline \multirow{2}{*}{$\begin{array}{l}\text { Na-hexameta- } \\
\text { foszfát } \\
\text { (Calgon) }\end{array}$} & \multirow{2}{*}{$\begin{array}{l}3 ; 4 ; 8 ; 9 ; 10 ; 11 ; \\
13 ; 23 ; 24 ; 25 ; 28 ; \\
30 ; 32 ; 33 ; 34 ; 37 \\
\quad 41 ; 45 ; 47 ; 57\end{array}$} & $3^{*}$ & $\begin{array}{c}36 \mathrm{kHz} ; 60 \\
\mathrm{w}\end{array}$ & 27 \\
\hline & & 4 & 35 W 100\% & $39 ; 44 ; 49$ \\
\hline \multirow{2}{*}{$\begin{array}{l}\text { Na-hexameta- } \\
\text { foszfát + Na- } \\
\text { bikarbonát }\end{array}$} & \multirow{2}{*}{$\begin{array}{c}2 ; 5 ; 22 ; 31 ; 39 ; \\
40 ; 48 ; 52 ; 54 ; 55 \\
56\end{array}$} & 4 & 35 W 75\% & $43 ; 55 ; 56$ \\
\hline & & 5 & - & $\begin{array}{c}4 ; 5 ; 16 ; 32 ; \\
37 ; 58\end{array}$ \\
\hline \multirow[t]{2}{*}{ Na-pirofoszfát } & \multirow{2}{*}{$\begin{array}{c}14 ; 17 ; 18 ; 19 ; 21 ; \\
22 ; 26 ; 38 ; 45 ; 56 ; \\
59\end{array}$} & 9,6 & $\begin{array}{c}\text { energy lvl. } \\
4 \\
\end{array}$ & 11 \\
\hline & & 10 & $35 \mathrm{kHz}$ & 26 \\
\hline $\begin{array}{c}\text { Na-pirofoszfát + } \\
\text { Na-bikarbonát }\end{array}$ & 15 & $3-10(3)$ & - & 31 \\
\hline Na-hidroxid & $12 ; 13 ; 16$ & $\begin{array}{c}0 / 6 / 8 / 9 \\
(8)\end{array}$ & - & 10 \\
\hline Na-oxalát & $12 ; 13$ & $\begin{array}{l}0 ; 2 ; 4 ; 6 ; \\
\quad 8 ; 10\end{array}$ & $\begin{array}{c}35 \text { W 75\%; } \\
100 \%\end{array}$ & 45 \\
\hline
\end{tabular}

*: mérés közben folyamatos ultrahangos kezelés; több vizsgált időtartam esetén zárójelbe tettük és dőlt betűvel jeleztük a szerzők által javasolt értéket 
A vizsgált közlemények (1. táblázat) egyharmada alkalmazott valamiféle roncsolásos előkezelést az aggregátumok kötőanyagainak eltávolítása céljából. Általában az ülepítéses módszereknél alkalmazott (szabványosított) előkészítési eljárásoknak megfelelően jártak el (vegyszerek, oldatkoncentrációk megválasztása) nyilvánvalóan az ülepítéses módszerekkel való összehasonlíthatóság céljából.

A vizsgálatok során elsősorban a humuszanyagokat roncsolták el hidrogénperoxidos kezeléssel, ritkábban találkoztunk a mész sósavas (esetleg Na-acetátos) kioldásával. Az LDM MÖ méréseket megelőzően az ISO 11277: 2009(E) szabványban javasolt teljes roncsolást (a humusz és mész mellett a vasoxi-hidroxidok kioldása) csak elvétve alkalmazták (2. táblázat).

Kémiai diszpergálást a vizsgált közlemények 72\%-ában végeztek az LDM MÖ méréseket megelözően. Diszpergálószerként legtöbbször nátrium-hexametafoszfátot $\left(\left(\mathrm{NaPO}_{3}\right)_{6}\right)$ vagy nátrium-pirofoszfátot $\left(\mathrm{Na}_{2} \mathrm{H}_{2} \mathrm{P}_{2} \mathrm{O}_{7}\right)$ használtak (2. táblázat). Ezzel szintén igazodni kívántak az ülepítéses módszerekre kidolgozott szabványokhoz (pl. a nemzetközi - ISO 11277:2009(E) az előbbi, míg a hazai szabvány - MSZ-08 0205-78 - az utóbbi alkalmazását írja elő). A diszpergáló oldatok koncentrációját nem minden esetben tüntették fel a szerzők.

A mechanikai diszpergálás során általában a mintát hosszabb-rövidebb ideig tartó, meghatározott erősségủ ultrahangos (a továbbiakban UH) kezelésnek vetik alá, melynek során az egyes aggregátumok szétesnek (GENRICH \& BREMNER, 1972). Több müszergyártó cég is beépíti az UH-os előkészítő egységet a mérőrendszerébe (1. táblázat). A mérőmüszerbe épített vagy hozzá kapcsolt előkészítő egység típusa (pl. az UH-os előkezelő rendszer geometriája), az előkészítés során alkalmazott keverési és szivattyúzási sebesség és az UH kezelés erőssége, illetve hossza egyaránt befolyásolja a mechanikai diszpergálás mértékét, és ezáltal a hatással van a mért MÖ eredményekre (CHAPPELL, 1998; RYŻAK \& BIEGANOWSKI, 2011). A gyártók ugyan megadnak beállítási protokollokat a termékeikhez, mely az egyes müszerek, illetve előkészítő egységek esetében eltérő lehet, ez azonban nem teremti meg feltétlenül a mérési eredmények összehasonlíthatóságát.

A 2. táblázatból látható, hogy a közlemények közel fele ( $52 \%$-a) nem alkalmazott UH-os előkezelést, vagy nem közölte ennek részleteit. A fennmaradó közleményekben a 30 másodpercestől a 10 perces UH-os diszpergálásig különböző időtartamokat találtunk, azonban a kezelések túlnyomó része három és öt perc közé esett. Még kevesebb az információ az UH-os kezelések erősségére vonatkozóan (a közlemények $\sim 15 \%$-a). A megadott értékek nehezen összehasonlíthatók, hiszen a készülékek müszerkönyvei sem nyújtanak egyértelmủ tájékoztatást az UH-kezelések erősségéről, illetve a beállítható fokozatok jelentéséről.

A 3. táblázatban a mechanikai diszpergálás másik két fontos tényezőjét, az elökészítő egységekbe épített keverő, illetve keringető rendszer szivattyúzási sebességét hasonlítottuk össze. 23 esetben $(\sim 39 \%)$ találtunk erre vonatkozó információt, főként a Mastersizer 2000 mérőműszer előkészítő egységeire vonatkozóan. A talajvizsgálatok céljára leginkább javasolható Hydro $\mathrm{G}$ egység esetében a legtöbbször alkalmazott keverési sebesség $600 \mathrm{rpm}$ (revolutions per minute; az egy percre eső fordulatok számát jelenti), míg a szivattyúzási sebesség $1750 \mathrm{rpm}$ volt. A Hydro MU előkészítő egységen ezzel szemben nem adható meg külön-külön a keverés és a 
szívattyúzás sebessége; a legtöbbször a 2500 rpm keverési és szivazttyúzási sebességgel találkoztunk a közleményekben.

Sok esetben, a tanulmányok több mint egy harmadánál, a mechanikai és kémiai diszpergálást egyidejüleg alkalmazták (2. és 3. táblázat). Egyes szerzők szerint a hosszú ideig tartó UH-kezelés vagy az UH-kezelés és a diszpergálószerek együttes hatására a már diszpergálódott részecskék újbóli koagulációja figyelhető meg, mely torzíthatja a valós szemcseeloszlási eredményeket (MCCAVE et al., 1986; CHAPPELL, 1998; RYŻAK \& BIEGANOWSKI, 2011). Amennyiben a mechanikai és kémiai diszpergálást együttesen alkalmazták, felmerült a kezelések sorrendjének kérdése is. A vizsgált közlemények jelentős többségében először a kémiai, majd a mechanikai diszpergálást végezték el. RYŻAK és BIEGANOWSKI (2011) tapasztalatai alapján első lépésben a kémiai diszpergálószerek alkalmazása javasolható, majd ezt kell, hogy kövesse egy 5 percnél nem hosszabb idejű ultrahangos diszpergálás.

\section{3. táblázat}

Az előkészítő egységek áramlási és keverő sebességének beállításai a vizsgált közleményekben

\begin{tabular}{|c|c|c|c|}
\hline Előkészítő egység & $\begin{array}{c}(2) \\
\text { Keverési } \\
\text { sebesség (rpm) }\end{array}$ & $\begin{array}{c}\text { (3) } \\
\text { Szívattyúzási } \\
\text { sebesség (rpm) }\end{array}$ & $\begin{array}{c}(4) \\
\text { Irodalom kódja }\end{array}$ \\
\hline \multirow{3}{*}{$\begin{array}{c}\text { Hydro G } \\
\text { (Mastersizer 2000) }\end{array}$} & 600 & 1750 & 51 \\
\hline & 700 & 1750 & $\begin{array}{c}42 ; 43 ; 44 ; 45 ; 48 ; 55 ; \\
56 ;\end{array}$ \\
\hline & 800 & 2000 & 54 \\
\hline $\begin{array}{c}\text { Hydro SM } \\
\text { (Mastersizer 2000) }\end{array}$ & \multicolumn{2}{|c|}{1200} & 50 \\
\hline \multirow{6}{*}{$\begin{array}{c}\text { Hydro MU } \\
\text { (Mastersizer 2000) }\end{array}$} & \multicolumn{2}{|c|}{1500} & 49 \\
\hline & \multicolumn{2}{|c|}{2500} & $\begin{array}{c}35 ; 36 ; 40 ; 42 ; 46 ; 51 ; \\
52 ;\end{array}$ \\
\hline & \multicolumn{2}{|c|}{$1200-3000(2500)$} & 39 \\
\hline & \multicolumn{2}{|c|}{$1600-2500(2500)$} & 56 \\
\hline & \multicolumn{2}{|c|}{2650} & 47 \\
\hline & \multicolumn{2}{|c|}{3000} & 41 \\
\hline $\begin{array}{l}\text { Fritsch Analysette } \\
22\end{array}$ & \multicolumn{2}{|c|}{$3600-4200$} & $20 ; 23 ; 24 ; 25$ \\
\hline
\end{tabular}

Az áttekintett közlemények közel egyharmada a Fritsch cég Laser Particle Size Analysette 22 müszernek valamelyik változatát használta (pl. KONERT \& VANDENBERGHe, 1997; Hernádi et al., 2008; Ferro \& MirabiLE, 2009; Di STEFANO et al., 2010; 2011; ANTINORO et aL., 2012; MADARÁSZ et al., 2012; KUn et al., 2013; KONDRLOVA et al., 2015; CENTERI et al., 2015). A müszertípus egyszerüen kezelhető, az előre beállítható mérési protokoloknak (SOP: Standard Operating Procedures) köszönhetően a minta behelyezése után automatikusan végzi a diszpergálást, a mérést és a mérési jelentés elkészítését (kiértékelést). Felszerelhető nedves 
és száraz diszpergálóegységgel, valamint mindkettőhöz automatikus minta előkészítő csatlakoztatható. A müszer az ISO 13320-as mérési protokollal dolgozik, ami nedves diszpergálás esetén a 0,1-2100 $\mu \mathrm{m}$ mérettartomány közé eső részecskék mérését teszi lehetővé. Az 57 elemből álló detektor két szegmensben (függőleges és vízszintes) fogadja a polarizált lézerfényt. A müszerrel egyszerre legfeljebb 110 mérettartomány mérhető. A mérésekhez használt paramétereket (refraktív index, adszorpciós tényező) a szerzők ritkán közlik részletesen, melynek oka feltehetően a müszer által nyújtott teljes automatizálás lehetősége (Fritsch Laser Particle Sizer Analysette 22 NanoTec Measuring Unit Description).

A közlemények szintén közel egyharmada valamilyen Malvern gyártmányú müszert használ az LDM MÖ mérésekhez (pl. MCCAVE et al., 1986; CHAPPELL, 1998; BITTELLI et al., 1999; BIEGANOWSKI et al., 2010; RYŻAK \& BIEGANOWSKI, 2011; MAKÓ et al., 2014; LAMORSKI et al., 2014; JoÓ et al., 2015; THOMAS \& REDSTEER, 2016). Ezek közül is legtöbbször a Mastersizer 2000 rendszereket alkalmazták. Ezek a müszerek a manuális mérés mellett szintén felkínálják az előre beállítható mérési protokolok használatát. Felszerelhetők többféle nedves (Hydro MU, Hydro G) és egyféle száraz (Scirocco 2000) diszpergáló egységgel. A Mastersizer 2000 müszer mérési tartománya $0,02-2000 \mu \mathrm{m}$. A müszer egy vörös hélium-neon lézer, valamint egy kék színủ szilárd-test fényforrást tartalmaz (Malvern Operators Guide, 1999).

A vizsgált szakirodalom fennmaradó részében (LOIZEAU et al., 1994; BUURMAN et al 1997; BEUSELINCK et al., 1998; BUURMAN et al., 2001; VANCASTEELE \& DE VOS, 2001; ESHEL et al., 2004; ZOBECK, 2004; ARRIAGA et al., 2006; GUZMÁN et al., 2010) a szerzők a Beckman Coulter cég müszereit használták a méréshez, jellemzöen az LS széria valamelyik modelljét (többségben az LS230-at). A rendszer 4 tagja (LS100, LS130, LS200, LS230) a mérési határokban tér el egymástól. A műszerhez 3 nedves (Fluid Module, Hazardous Fluid Module, Micro Volume Module) valamint 1 száraz (Dry Powder Module) diszpergáló egység csatlakoztatható. A vörös fényủ lézer fényét három, az alacsony, közepes és magas szögben beeső polarizált fény mennyiségét mérő detektor fogja fel. Ezek a gépek nem a legkorszerübbek, így a beállítások automatizálása nem, vagy kevésbé lehetséges (Coulter LS series Product Manual).

Összesen két közleményben találkoztunk a Horiba müszercsalád termékeinek talajvizsgálati célú alkalmazásával (SEGAL et al., 2009; KowALENKO \& BABUIN, 2013).

A műszertípusok közül talán az Analysette 22 termékcsalád kezelése a legkönynyebben elsajátítható. A Mastersizer 2000 használata kicsit bonyolultabb, viszont a mérések némiképp jobban reprodukálhatóak. A Coulter LS széria tagjai teljesítményükben nem tudják felvenni a versenyt az előző két modellel, előnyük viszont az, hogy ezek a legolcsóbb eszközök.

A tapasztalatok szerint az LDM MÖ mérési eredményeket nagymértékben befolyásolja a vizsgált talajszuszpenzió koncentrációja, vagyis a szuszpenzióban lévő részecskék száma. A mérőrendszerbe adagolt talajminta mennyiségét a szuszpenzió „fénygyengítési mutatója” (,obscuration” elhomályosulás) szabja meg, melyet a müszer adagolás közben mér és folyamatosan jelez. A „fénygyengítési mutató” azt 
jelzi, hogy a lézerfényt milyen mértékben „homályosítják” el a mérendő talajrészecskék. A Mastersizer 2000 készülék gyártója pl. a 10\% és 20\% közötti értékeket javasolja: $10 \%$ alatt a részecskék száma túl kicsi ahhoz, hogy megbízható eredményeket kapjunk, míg a $20 \%$ feletti érték esetében a nagyszámú részecske miatt a lézerfény másodlagos fénytörése következhet be, ami az LDM MÖ mérések hibájához vezethet (Malvern Operators Guide, 1999).

A vizsgált közlemények $~ 36 \%$-a közölte a vizsgált talajszuszpenzió „fénygyengítési mutatóját", mely az esetek nagy részében a fenti tartományon belül esett (4. táblázat).

\section{4. táblázat}

A talajszuszpenzió „fénygyengítési” tartománya (obscuration) a mérések során a vizsgált közleményekben

\begin{tabular}{|c|c|}
\hline „Fénygyengítési mutatô" (obscuration) & $\begin{array}{c}(2) \\
\text { Irodalom kódja }\end{array}$ \\
\hline$\sim 10$ & $6 ; 7 ; 12 ; 13 ;$ \\
\hline $10 \pm 3$ & 9 \\
\hline $7-13$ & 30 \\
\hline $7-15$ & 22 \\
\hline $8-10$ & $5 ; 50$ \\
\hline $8-12$ & 14 \\
\hline $10-20^{*}$ & $35 ; 36 ; 38 ; 39 ; 42 ; 43 ; 49 ; 51$ \\
\hline$\sim 20$ & 54 \\
\hline $18-25$ & 46 \\
\hline$\sim 45$ & 34 \\
\hline
\end{tabular}

A mérési idő hosszának megválasztása is hatással lehet a mért LDM MÖ értékekre. A hosszabb mérési idő alatt a detektorok több „felvételt” készítenek, ami statisztikailag csökkenti a mérési bizonytalanságot. Másrészről a rutin sorozatvizsgálatok elvégzése a mérés időtartamának a lecsökkentését kívánja meg. A Mastersizer 2000 készülék 1-131 s közt teszi lehetővé a mérési idő beállítását. A szakirodalom sajnos csak elvétve közöl információkat a mérések időtartamáról (pl. GoOSSENS et al., 2014; SOCHAN et al., 2014). RYŻAK és BIEGANOWSKI, 2011) vizsgálatai szerint a Mastersizer 2000 mérőeszköz esetében 30 s mérési idő (30 s vörös fényben és $30 \mathrm{~s}$ kék fényben) már reprezentatív mérésekre nyújtott lehetőséget.

Két különbözö diffrakciós modell szerint számolható a részecskék méret szerinti eloszlása a diffrakciós képből: a Fraunhoffer-közelítés és a Mie-elmélet alapján (DE BOER et al., 1987; DI STEFANO et al., 2010). Mindkét elmélet gömbszerü szemcséket feltételez. Nem gömbszerü szemcsék esetében egy azzal egyenértékủ, gömbszerủ szemcsékre vonatkozó részecskeméret eloszlást kapunk.

A Fraunhofer-közelítés esetében az abszorpciós és refrakciós indexek közti különbségek hatásai elhanyagolhatóak, míg a Mie-elmélet alkalmazásakor a részecskék ásványi összetételétől függő refrakciós index (törésmutató) és abszorpciós in- 
dex értékeit meg kell adnunk (becsülnünk) (EsHEL et al., 2004). (Egy optikai közeg refrakciós indexe vagy törésmutatója (RI) a fény vákuumban mért sebességének (c = $299792458 \mathrm{~m} / \mathrm{s}$ ) és a fény adott optikai közegben mért fázissebességének (v) a hányadosa. Levegő esetében ennek értéke 1,000293. Az abszorpciós index vagy elnyelési tényező egy olyan viszonyszám, ami megmutatja, hogy az adott felületre merőlegesen érkező fénysugarakból mekkora az elnyelődés mértéke: amennyiben ez a szám 1, akkor a beérkező fénysugarakat az anyag teljes mértékben elnyelte (HIRLEMANN et al., 1984).) A Fraunhofer-közelítés esetében a részecskék lényegesen nagyobbak, mint a fény hullámhossza, azaz ilyenkor a szórási képet legföképpen a fény elhajlása (diffrakció) hozza létre. Ilyenkor a részecskék méretére vonatkozó információkat a szemcsék felületén megtört fény kis elhajlási szögei $\left(<35^{\circ}\right)$ szolgáltatják. A Mie-elmélet használata akkor javasolható, ha a fény hullámhossza kisebb, vagy megközelítőleg ugyanakkora, mint a mérendő részecskék mérete. Minél kisebb egy részecske, annál nagyobb hatással van jelen a szórási kép létrejöttében a fénytörés (refrakció) és a fényelnyelés (abszorpció). Speciális esetben a szórási kép Mie-elmélet szerinti értelmezése tartalmazza a Fraunhofer-elhajlást is; így a Mie-elmélet használható a talajrészecskék teljes mérettartományában (DE BOER et al., 1987).

A szemeloszlási görbék számolásához szükséges mérőmüszer-beállítások (Fraunhofer vagy Mie diffrakciós modell kiválasztása, az abszorpciós vagy a fénytörési mutatók megadása) alapvetően megváltoztathatják az eredményeket - azonban ezek a paraméterek a mérések után szabadon megváltoztathatók és az eredmények igény szerint újra számolhatók (KERRY et al., 2009; ÖZER et al., 2010; RYŻAK \& BIEGANOWSKI, 2011; KONDRLOVA et al., 2015).

A Fraunhofer-közelítés használata esetén mentesülünk az optikai paraméterek (refrakció, abszorpció) pontatlan megválasztása folytán fellépő hibalehetőségektől. Ez a modell azonban - a fentiek alapján - csak az $50 \mu \mathrm{m}$ feletti szemcseméretü homogén minták esetén ad megfelelő eredményt. Mivel a legtöbb talajminta szemcsemérete igen heterogén (polidiszperz minták), ezért viszonylag szük az a mintatartomány, ahol a Fraunhofer-közelítést nagy biztonsággal tudjuk alkalmazni (WEINER, 1984). A Mie-elmélet alkalmazásával pontosabb MÖ eredményeket kapunk a nagyobb agyagtartalommal rendelkező talajokra (DE BoER et al., 1987). E modell használata esetén azonban rendkívül fontos, hogy az optikai paramétereket a lehető legpontosabban határozzuk meg, állítsuk be a mérési eredmények kiértékelése során. Mivel egy talajminta általában nem azonos optikai tulajdonságú szemcséket tartalmaz, az egységes beállítások használata óhatatlanul mérési pontatlanságokhoz vezet. A vizsgált közlemények közel $72 \%$-ban tájékoztatást nyújtanak az alkalmazott optikai modellről. Túlnyomó részük a Mie-elmélet szerint számolta a részecskék megoszlását (5. táblázat). 
5. táblázat

Az optikai modell megválasztása a vizsgált közleményekben

\begin{tabular}{|c|c|}
\hline $\begin{array}{c}(1) \\
\text { Optikai modell }\end{array}$ & $(2)$ \\
\hline Mie & $6 ; 7 ; 8 ; 9 ; 10 ; 12 ; 13 ; 14 ; 21 ; 29 ; 30 ; 34 ; 35 ; 37 ; 41 ; 42 ; 43 ; 44 ; 45 ;$ \\
& $46 ; 48 ; 51 ; 52 ; 53 ; 54 ; 55 ; 56$ \\
\hline Fraunhofer & $2 ; 5 ; 17 ; 25 ; 26 ; 32$ \\
\hline Mie \& Fraunhofer & $1 ; 19 ; 23 ; 24 ; 28 ; 36 ; 38 ; 39 ; 49$ \\
\hline
\end{tabular}

A vizsgált közleményekben a Mie-elmélet alkalmazása során a műszerbeállítások jellemzően 1,5 körüli szilárd fázisra vonatkoztatott refrakciós index (törésmutatóval; RI) és 0,1 körüli adszorpciós index (AI) voltak (6. táblázat).

\section{6. táblázat}

Az optikai paraméterek megválasztása a vizsgált közleményekben

\begin{tabular}{|c|c|c|c|}
\hline $\begin{array}{c}\text { (1) } \\
\text { Abszorpciós index } \\
\text { (AI) }\end{array}$ & $\begin{array}{c}(2) \\
\text { Irodalom kódja }\end{array}$ & $\begin{array}{c}\text { (3) } \\
\text { Szilárd fázis törésmuta- } \\
\text { tója }(\mathbf{R I})\end{array}$ & $\begin{array}{c}(2) \\
\text { Irodalom } \\
\text { kódja } \\
\end{array}$ \\
\hline 0 & $1 ; 36,50,51$ & 1,15 & 32 \\
\hline 0,001 & $10 ; 38 ; 52$ & 1,42 & 52 \\
\hline 0,01 & $12 ; 13 ; 41$ & 1,50 & 13 \\
\hline 0,1 & $\begin{array}{c}34 ; 35 ; 42 ; 43 ; 44 ; 46 ; \\
48 ; 53 ; 55 ; 58\end{array}$ & 1,52 & $\begin{array}{c}16 ; 42 ; 43 ; \\
44 ; 45 ; 48 \\
51 ; 55\end{array}$ \\
\hline 0,2 & 8 & 1,53 & $34 ; 37 ; 54 ; 58$ \\
\hline $0 / 0,01 / 0,1 / 1(1)$ & 39 & 1,54 & 50 \\
\hline $0,1 / 0,2$ & 30 & 1,55 & $41 ; 53$ \\
\hline $0,01 / 0,1 / 1$ & 45 & 1,56 & $6 ; 7 ; 9$ \\
\hline $0,001-0,2(0,1-0,2)$ & 28 & 1,57 & $36 ; 38$ \\
\hline $0,001 / 0,01 / 0,05 / 0,1 / 1(1)$ & 49 & 1,58 & $35 ; 46$ \\
\hline $0,15,0,20$ & $6 ; 7$ & $1,40-1,54(1,42)$ & 10 \\
\hline \multirow[t]{8}{*}{$0 / 0,1 / 1(0,1)$} & \multirow[t]{8}{*}{56} & $\begin{array}{c}1,48-1,71 ; 2,9-3,2 \\
(1,50)\end{array}$ & 8 \\
\hline & & $1,3-1,8(1,50)$ & 28 \\
\hline & & $1,45-1,65$ & 1 \\
\hline & & $1 / 1,2 / 1,52 / 1,7 / 2(1,52)$ & 49 \\
\hline & & $1,44 / 1,50$ & 30 \\
\hline & & $\begin{array}{l}1,45-1,70 \\
(1,50-1,60) \\
\end{array}$ & 12 \\
\hline & & $\begin{array}{c}1,43-3,22 \\
(1,5-1,6)\end{array}$ & 39 \\
\hline & & $1,5,1,6(1,53)$ & $24 ; 25$ \\
\hline
\end{tabular}

Több vizsgált AI és RI esetén zárójelbe tettük és dölt betüvel jeleztük a szerzök által javasolt értéket 
Egyes szerzők hangsúlyozták, hogy a lézeres szemcsemérés tekintetében a refrakciós index értéke inkább standardizálható, míg az abszorpciós index megfelelő megválasztása inkább talajminta-függő (RYŻAK \& BIEGANOWSKI, 2011; GOOSSENS et al., 2014).

\section{Az LDM MÖ mérések eredményeinek összehasonlítása más módszerekkel kapott eredményekkel - a konverzió lehetöségei}

A LDM MÖ vizsgálatok során kapott részecskeméret eloszlások eltérhetnek a szitálással és az ülepítéses módszerek valamelyikével kapott eloszlásoktól. Bőséges szakirodalom áll rendelkezésre, mely az LDM és a pipettás módszerrel kapott MÖ vizsgálati eredményeket (pl. LOIZEAU et al., 1994; KONERT \&VANDENBERGHE, 1997; MugGLER et al., 1997; BEUSELINCK et al., 1998; BUURMAN et al., 2001; VANDECASTEELE \& DE Vos, 2001; XU \& Di GuIDA, 2003; Eshelet al., 2004; ARRIAGA et al., 2006; HERNÁDI et al., 2008; TAUBNER et al., 2009; KUN et al., 2013; YANG et al., 2015; MAKÓ et al., 2016a;b; FISHER et al., 2017), vagy a hidrométeres mérések és a LDM mérések eredményeit (pl. RYŻAK et al., 2004; FERRO \& MirABle, 2009; SEgAL et al., 2009; RyŻAK \& BIEGANOWSKI, 2010; LAMORSKI et al., 2014; FENTON et al., 2015) hasonlítja össze. A szerzők általában egyetértenek abban, hogy a LDM többé-kevésbé kisebb mennyiségü agyagtartalmat és nagyobb arányú portartalmat mér, mint az ülepítéses módszerek. A mért homoktartalmakban általában nincs számottevő eltérés.

A lézerdiffrakcióval mért kisebb agyagtartalmakat általában az agyagfrakciót alkotó talajrészecskék gömbszerütől való eltérő alakjával magyarázzák (MATSUYAMA \& YAMAмото, 2004; BlotT \& Pye, 2006; Fedotov et al., 2007; PolAKOWSKi et al., 2014). Azt azonban szintén megállapítják, hogy az eltérő müszertípusok, müszerbeállítások, az előkezelési módszerek bizonytalanságai megnehezítik a mérési eredmények összehasonlítását, a módszerek közti konverziós technikák kidolgozását (RYŻAK \& BIEGANOWSKI, 2011; MADARÁSZ et al., 2012; SOCHAN et al., 2012; CENTERI et al., 2015).

KONERT és VANDENBERGHE (1997) véletlenszerüen kiválasztott holland talajmintákon végzett mérései és számításai szerint a pipettás eljárással mért $2 \mu \mathrm{m}$ alatti agyagtartalom a lézeres mérések esetén a $8 \mu \mathrm{m}$ alatti tartománynak feleltethető meg. A $8 \mu \mathrm{m}$-es agyag/por mérettartomány határ alkalmazását azután rájuk hivatkozva több szerző is átvette (pl. FENTON et al., 2015). A két módszer pontos szemcseméret-tartomány megfeleltetése azonban még mindig a vitatott kérdések közé tartozik. VANDECASTEELE és DEVOS (2001) belga talajadatbázison végzett összehasonlító elemzései szerint a 0-6 $\mu$ m-es LDM agyagfrakció mutatta a legpontosabb egyezést a 0-2 $\mu \mathrm{m}$-es, pipettás mérésekből származó agyagtartalmakkal. PABST és munkatársai (2000) kaolin és egyéb típusú agyagok vizsgálata során a 3-5 $\mu$ m-es LDM agyag/por mérettartomány határ megválasztását találta a legpontosabbnak a pipettás mérésekkel való összehasonlításhoz. BUURMAN és munkatársai (2001) megállapították, hogy a 2 és $8 \mu \mathrm{m}$ közötti tartományban üledéktípusonként különkülön elvégzett statisztikai összehasonlító elemzésekkel állapítható csak meg pontosan a legalkalmasabb LDM agyag/por mérettartomány határ. Meszes alapkőzeten 
kialakult talajok esetében a LDM méréseknél KERRY és munkatársai (2009) az agyag felső határának a $4 \mu$ m-t javasolták. Hazai nagyszámú (157db) talajmintán végzett összehasonlító elemzés eredményei alapján ezt a határt 6,6 $\mu \mathrm{m}$ (később pontosítva: $7 \mu \mathrm{m}$ ) értéknél állapították meg (BARNA et al., 2015; MAKÓ et al., 2016b;c).

\section{Aggregátum-stabilitás mérések lézerdiffrakciós méréstechnikával}

A talajok szerkezetessége olyan fontos tulajdonság, mely alapvetően meghatározza azok mechanikai, hidrológiai, mikrobiológiai és ezáltal tápanyaggazdálkodási, termékenységi sajátságait. A talaj aggregátum-stabilitása arról ad tájékoztatást számunkra, hogy a szerkezeti tulajdonságok hogyan változnak az idő függvényében különféle degradációs hatásokra (pl. talajmüvelő eszközök mechanikai, eső vagy öntözővíz szétiszapoló hatása), illetve milyen egy adott talaj víz- vagy szélerózióra való hajlama. Az aggregátumok stabilitásának vizsgálatát úgy végezzük, hogy az egyes aggregátumokat ismert nagyságú romboló erőnek vetjük alá, majd megmérjük az ennek hatására épen maradt aggregátumok mennyiségét és tömegét.

\section{7. táblázat}

Aggregátum-stabilitási mérések lézerdiffrakciós méréstechnikával a szakirodalomban készülék típusonként és előkészítő egységenként rendszerezve

\begin{tabular}{|c|c|c|c|}
\hline $\begin{array}{c}(1) \\
\text { Készülék } \\
\text { típusa } \\
\end{array}$ & $\begin{array}{c}\text { (2) } \\
\text { Előkészítő } \\
\text { egység } \\
\end{array}$ & $\begin{array}{c}\text { (3) } \\
\begin{array}{c}\text { Vizsgált minta típusa } \\
\text { (mintaszám) }\end{array} \\
\end{array}$ & $\begin{array}{l}(4) \\
\text { Irodalom }\end{array}$ \\
\hline \multirow{2}{*}{$\begin{array}{l}\text { B.-Coulter } \\
\text { LS } 230\end{array}$} & - & spanyol talajok (vízgyüjtő) (20) & AMÉZKETA et al., 2003. \\
\hline & - & USA vályog fizikai féleségű talaj & $\begin{array}{l}\text { FRISTENSKY \& GRISMER, } \\
2009 .\end{array}$ \\
\hline $\begin{array}{l}\text { B.-Coulter } \\
\text { LS } 13320\end{array}$ & - & $\begin{array}{l}\text { Kelet-angliai talajok (vízgyüjtő) } \\
(30)\end{array}$ & RAWLINS et al., 2013. \\
\hline \multirow{5}{*}{$\begin{array}{l}\text { Mastersizer } \\
2000\end{array}$} & Hydro MU & $\begin{array}{c}\text { lengyel erdőtalajok, glejes talajok, } \\
\text { csernozjom talajok (3) }\end{array}$ & $\begin{array}{l}\text { BIEGANOWSKI et al., } \\
2010 .\end{array}$ \\
\hline & Hydro MU & USA és ausztrál talajminták (7) & MASON et al., 2011. \\
\hline & - & spanyol talajok (3) & VIRTO et al., 2011. \\
\hline & Hydro G & $\begin{array}{l}\text { löszön képződött barna erdőtala- } \\
\text { jok (különféle kezelések után) }\end{array}$ & $\begin{array}{l}\text { JOZEFACIUK \& CZACHOR, } \\
2014 . \\
\end{array}$ \\
\hline & - & $\begin{array}{c}\text { USA erdő- és csernozjom talajok; } \\
\text { eolikus üledékek }\end{array}$ & MASON et al., 2016. \\
\hline Cilas 1180 & - & tartamkísérletek talajai (Acrisols) & BORTOLUZZI et al., 2010. \\
\hline $\begin{array}{c}\text { Fritsch } \\
\text { Analysette } \\
22 \\
\end{array}$ & - & orosz csernozjom talaj (10) & SHEIN et al., 2006. \\
\hline
\end{tabular}

Az aggregátum-stabilitás mérésére számos módszer található a szakirodalomban, a legelterjedtebb az ún. nedves szitálásos módszerek valamelyik változata (pl. 
KEMPER \& RosenaU, 1986; Le BissonNAIS, 1996). Elönyük, hogy azonos módszerrel előkészített, azonos mérési körülmények között mért minták esetén egymással öszehasonlítható értékeket kapunk. A nedves szitálási módszerek legfőbb korlátjai, hogy elsősorban a makroaggregátumok stablitásának mérésére alkalmasak, a stabil aggregátumokat csak néhány meghatározott mérettartományban képesek mérni, a szétiszapolódott részecskék további szemcseméret-eloszlását nem tudják vizsgálni, illetve - nem utolsósorban - rendkívüli módon munkaigényesek.

A lézeres szemcseeloszlás vizsgálatok módszertana az aggregátum-stabilitás mérések fenti korlátait részben képes kiküszöbölni, bár talajfizikai alkalmazása korántsem terjedt el még annyira, mint a LDM MÖ vizsgálatoké (7. táblázat).

\section{Összefoglalás}

A lézerdiffrakciós szemcseanalízis egy korszerü módszer a talajmechanikai vizsgálatokban, ám egy egységes mérési szabvány bevezetése (akár müszerhez köthetően) nagymértékben növelné a mérések reprodukálhatóságát. A mérések tekintetében kiemelt szerepe van az előkészítő módszereknek (talajszerkezetet kialakító kötőanyagok roncsolása, elemi szemcsék diszpergálása), azonban ezen a téren is hiányzik az egységes szabványosítás. A tanulmányozott közlemények alapján megállapítható, hogy mind az optimális mintaelőkészítési módszer, mind pedig a legmegfelelőbb műszerbeállítás nagymértékben függ a mérni kívánt minta fizikai és kémiai sajátságaitól. A mérési eredmények hagyományos ülepítéses módszerrel kapott eredményekkel történő összehasonlítására szolgáló konverziós módszerek (frakció mérethatárváltások, illetve konverziós egyenletek) használhatósága is talajminta- és LDM vizsgálati módszer-függő. A lézeres szemcseanalízis alkalmazása a talajok aggregátum-stabilitás vizsgálata során ígéretes módszertani lehetőség, ám a mérések értelmezése és az összahasonlíthatóság megteremtése végett ezen a téren is elkerülhetetlen a szabványosítás.

Kulcsszavak: lézerdiffrakció, mechanikai összetétel, aggregátum-stabilitás, konverziós lehetőségek, talajfizikai szabványok

Kutatásunkat T048302 sz. OTKA és a K119475 sz. NKFI pályázatok és az Emberi Erőforrások Minisztériuma Új Nemzeti Kiválóság Programjának támogatásával végeztük.

\section{Irodalom}

Allen, T. A., 1990. Particle size measurement. $4^{\text {th }}$ ed., Chapman and Hall. London.

AMÉZKETA, E., AragüÉs, R., CARRANZA, R. \& URGEL, B., 2003. Macro- and microaggregate stability of soils determined by a combination of wet-sieving and laserray diffraction. Spanish Journal of Agricultural Research. 1 (4). 83-94.

Antinoro, C., Bagarello, V., Ferro, V., Giordano, G. \& Iovino, M., 2012. Testing the shape-similarity hypothesis between particle-size distribution and water retention for Sicilian soils. Journal of Agricultural Engineering. 43. 114-122. 
ARriaga, F. J., LOWERY, B. \& MAYS, M. D., 2006. A fast method for determining soil particle size distribution using laser instrument. Soil Sci. 171. 663-674.

Balashov, E., KREN, J. \& PRochazKova, B., 2010. Influence of plant residue management on microbial properties and water-stable aggregates of two agricultural soils. Int. Agrophys. 24. 9-14.

Balázs, R.,NÉmeth, T., MAKó, A., Kovács Kis, V. \& KereszTes, M., 2011. A mechanikai összetétel meghatározása során alkalmazott minta-előkészítés talajásványtani hatása. In: LIII. Georgikon Napok konferenciakiadványa. Keszthely. 2011. Szept. 29-30. 73-83.

BARNA, GY., Szabó, J., BAKACSI, Zs., KoÓs, S., LÁszló, P., HAUK, G., RAJKAI, K. \& MAKÓ, A., 2015. Effect of particle size limit values on predicted soil hydraulic conductivity. In Proc. of "Transport of Water, Chemicals and Energy in the SoilPlant-Atmosphere System". 22 $2^{\text {nd }}$ Poster day (Ed.: ČElKOVÁ, A. ). Institute of Hydrology of SAS. Bratislava, November 12, 2015. 16-23.

Beckman Coulter: Users manual for Beckman-Coulter LS Series. Brea, California, USA: www.beckmancoulter.com

Beuselinck, L., Govers, G., Poesen, J., Degraer, G. \& Froyen, L., 1998. Grain-size analysis by laser diffractometry: comparison with the sieve-pipette method. Catena. 32. 193-208.

Bieganowski, A., Chojecki, T., RyżaK, M., Sochan, A. \& LAMORSKI, K., 2013. Methodological aspects of fractal dimension estimation on the basis of particle size distribution. Vadose Zone J. 12 (1). 1-9.

Bieganowski, A., ŁAGóD, G., RYŻAK, M., Montusiewicz, A., ChOMCZYŃSKA, M. \& SOCHAN, A., 2012. Measurement of activated sludge particle diameters using laser diffraction method. Ecological Chemistry and Engineering S. 19. 597-608.

BIEGANOWSKI, A., RYŻAK, M. \& WITKOWSKA-WALCZAK, B., 2010. Determination of soil aggregate disintegration dynamics using laser diffraction. Clay Miner. 45. 2334.

Bittelli, M., CAmpbell, G. S. \& Flury, M., 1999. Characterization of particle-size distribution in soils with fragmentation model. Soil Sci. Soc. Am. J. 63. 782-788.

Blott, S. J. \& PyE, K., 2006. Particle size distribution analysis of sand-sized particles by laser diffraction: an experi-mental investigation of instrument sensitivity and the effect of particle shape. Sedimentology. 53.671-685.

Booth, A. C., Fullen, M. A., Jankauskas, B. \& JANKAuskienĖ, G., 2003. International calibration of the textural properties of Lithuanian eutric albeluvisols. Žeměs ûkio mokslai. 4. 3-10.

Bortoluzzi, E. C., Poleto, C., Baginski, Á. J. \& DA Silva, V. R., 2010. Aggregation of subtropical soil under liming: a study using laser diffraction. Rev. Bras. Ciênc. Solo. 34 (3). 725-734.

BoumA, J., 1989. Using soil survey data for quantitative land evaluation. In: Advances in Soil Science (Ed.: STEWART, B. A.). 177-213.

Brzeziñska, M., Nosalewicz, M., PaszTelan, M. \& WlodarczyK, T., 2012. Methane production and consumption in loess soil at different slope position. Scientific World J., Article ID 620270.

Buah-Bassuah, P. K., Euzzor, S., Francini, F., Quansah, G. W. \& Sansoni, P., 1988. Soil textural classification by a photosedimentation method. Appl. Opt. 37. 586-593. 
Budhu, M., Giese, R. F., CAMPBell, G. JR. \& BAumgrass, L., 1991. The permeability of soils with organic fluidds. Canadian Geotechnical Journal. 28. 140-147.

Butrman, P., PAPE, TH., \& MugGler, C. C., 1997. Laser grain-size determination in soil genetic studies. 1. Practical problems. Soil Sci. 162. 211-218.

Butrman, P., Pape, Th., Reijneveld, J. A., De Jong, F. \& VAN Gelder, E., 2001. Laser diffraction and pipette-method grain sizing of Dutch sediments: correlation for fine fractions of marine, fluvial, and loess samples. Geologie en Mijnbouw/Netherlands Journal of Geosciences. 80. 49-57.

BÜRKHOLZ, A. \& POLKE, R., 1984. Laser diffraction spectrometers/Experience in particle size analysis. Part. Part. Syst. Charact. 1. 153-160.

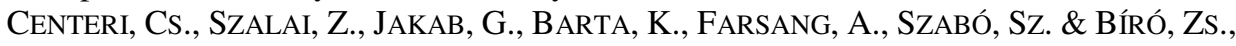
2015. Soil erodibility calculations based on different particle size distribution measurements. Hun. Geo. Bull. 64. 17-23.

CHAPPELl, A., 1998. Dispersing sandy soil for the measurement of particle size distributions using optical laser diffraction. Catena. 31. 271-281.

Clifton, J., Mcdonald, P., Plater, A. \& Oldfield, F., 1999. An investigation into the efficiency of particle size separation using Stokes' measurement. Earth Surf. Process. Landf. 24. 725-730.

Cooper, L. R., Haverland, R. L., Hendricks, D. M. \& Knisel, W. G., 1984. Microtrac particle-size analyzer: an alternative particle-size determination method for sediment and soils. Soil Sci. 138 (2). 138-146.

CziBulya, Zs., Tombácz, E., Szegi, T., Michéli, E. \& Zsolnay, Á., 2010. Standard state of soil dispersions for rheological measurements. Appl. Clay Sci. 48. 594601.

De Boer, G. B. J., De Weerd, C., Thoenes, D. \& Goossens, H. W. J., 1987. Laser diffraction spectrometry: Fraunhofer versus Mie scattering. Part. Part. Syst. Charact. 4. 14-19.

Di Gléria, J., Klimes-SzMiK, A. \& DvoracseK, M., 1957. Talajfizika és Talajkolloidika. Akadémiai Kiadó, Budapest.

Di Stefano, C., Ferro, V. \& Mirabile, S., 2010. Comparison between grain-size analyses using laser diffraction and sedimentation methods. Biosyst. Eng. 106. 205-215.

Di Stefano, C., Ferro, V. \& Mirabile, S., 2011. Testing the grain-size distribution determined by laser diffractometry for sicilian soils. Journal of Agricultural Engineering. 3. 39-46.

Dragun, J., 1998. The soil chemistry of hazardous materials. $2^{\text {nd }}$ ed. Amherst. Massachusetts.

ERTLi, T., MARTON, A. \& FöldÉNYI, R., 2004. Effect of pH and the role of organic matter in the adsorption of isoproturon on soils. Chemosphere. 57. 771-779.

Eshel, G., LeVy, G. J., Mingelgrin, U. \& Singer, M. J., 2004. Critical evaluation of the use of laser diffraction for particle-size distribution analysis. Soil Sci. Soc. Am. J. 68. 736-743.

Fedotov, G. N., Shein, E. V., Putlyaev, V. I., Arkhangel'skaya, T. A., Eliseev, A. V. \& MilanovsKiI, E. YU., 2007. Physicochemical bases of differences between the sedimentometric and laser-diffraction techniques of soil particle-size Analysis. Eurasian Soil Sci. 40 (3). 281-288. 
Fenton, O., Vero, S., Ibrahim, T. G., Murphy, P. N. C., Sherriff, S. C. \& HUALlaCháIN, D. Ó., 2015. Consequences of using different soil texture determination methodologies for soil physical quality and unsaturated zone time lag estimates. J. Contam Hydrol. 182. 16-24.

FERro, V. \& MirabiLE, S., 2009. Comparing particle size distribution analysis by sedimentation and laser diffraction method. Journal of Agricultural Engineering 2. 35-43.

Fisher, P., Aumann, C., Chia, K., O'Halloran, N. \& Chandra, S., 2017. Adequacy of laser diffraction forsoil particle size analysis. PLoS ONE. 12. (5). e0176510.

FRISTENSKY, A. J. \& GRISMER, M. E., 2009. Evaluation of ultrasonic aggregate stability and rainfall erosion resistance of disturbed and amended soils in the Lake Tahoe Basin, USA. Catena. 79. 93-102.

FRITSCH: Users manual for Fritsch Laser Particle Sizer Analysette 22 Nanotec Measuring Unit. Idar-Oberstein, D: FRITSCH GmbH - Sizing and Miling www.fritsch-international.com

Gantenbein, D., Schoelkopf, J., Matthews, G. P. \& Gane, P. A. C., 2011. Determining the size distribution-defined aspect ratio of platy particles. Appl Clay Sci. 53 (4). 544-552.

GEE, G. W. \& BAUdER, J. W., 1986. Particle-size analysis. In: Methods of soil analysis. Part 1. (Ed.: KLUTE, A.) $2^{\text {nd }}$ ed. Agron. Monogr. 9. ASA and SSSA, Madison, WI. 383-411.

GENRICH, D. A. \& BREMnER, J. M., 1972. A reevaluation of the ultrasonic vibration method of dispersing soils. Soil Sci. Soc. Amer. Proc. 36. 944-947.

Goossens, D., 2008. Techniques to measure grain-size distributions of loamy sediments: a comparative study of ten instruments for wet analysis. Sedimentology. 55. 65-96.

Goossens, D., BuCK, J., Teng, Y., Robins, C. \& Goldstein, H. L., 2014. Effect of sulfate and carbonate minerals on particle-size distributions in arid soils. Soil Sci. Soc. Am. J. 78. 881-893.

GuZMÁn, G., GÓMEZ, J. A. \& GIRÁLDEZ, J. V., 2010. Measurement of particle size distribution of soil and selected aggregate sizes using the hydrometer method and laser diffractometry. Geophysical Research Abstracts Vol. 12, EGU2010-4422-1.

HAJNOS, M., LIPIEC, J., SWIEBODA, R., SOKOŁOWSKA, Z. \& WiTKOWSKA-WALCZAK, B., 2006. Complete characterization of pore size distribution of tilled and orchard soil using water retention curve, mercury porosimetry, nitrogen adsorption, and water desorption methods. Geoderma. 135. 307-314.

HALL, A. D., 1904. The mechanical analysis of soils and the composition of the fractions resulting therefrom. J. Chem. Soc. Trans. 85. 950-963.

Hamamoto, S., Moldrup, P., KAWAmoto, K. \& Komatsu, T., 2009. Effect of particle size and soil compaction on gas transport parameters in variably saturated, sandy soils. Vadose Zone J. 8. 986-995.

HeRnÁDI, H., MAKó, A., BIEGANOwsKi, A. \& RYŹAK, M., 2012. Talajminták különböző szabványok szerint előkészített szemcseösszetételének meghatározása ülepítéses és optikai eljárással. Talajvédelem Különszám. 227-236.

Hernádi, H., Makó, A., Kucsera, S., Szabóné Kele, G. \& Sisák, I., 2008. A talaj mechanikai összetételének meghatározása különböző módszerekkel. Talajvédelem különszám. 105-114. 
HIRlEMAN, E. D., OEEHSK, V. \& CHIGIER, N. A., 1984. Response characteristics of laser diffraction particle size analysers: optical sample volume extent and lens effects. Opt. Eng. 23. 610-619.

ISO 11277: 2009 (E). Soil quality - Determination of particle size distribution in mineral soil material - Method by sieving and sedimentation. International Organization for Standarization, Geneva, Switzerland.

ISO 13320: 1999. Particle size analysis - laser diffraction methods - part 1. International Organization for Standarization, Geneva, Switzerland.

JACKSON, M. L., 1958. Soil chemical analysis. Prentice Hall. Englewood Cliffs, N.J.

JenA, R. K., JAGADEESWARAN, R. \& SivasAmy, R., 2013. Analogy of soil parameters in particle size analysis through laser diffraction techniques. Indian Journal of Hill Farming. 26. 79-83.

Joó, Sz., Tóth, J. \& FöldÉNYI, R., 2015. Characterization of salt- and surfactantcontaining sandy soil extracts by laser light methods. International Agrophysics 29. 291-298.

JOZEFACIUK, G. \& CZACHOR, H., 2014. Impact of organic matter, iron oxides, alumina, silica and drying on mechanical and water stability of artificial soil aggregates. Assessment of a new method to study water stability. Geoderma. 221-222. 1-10.

KeMPer, W. D. \& RosenaU, R. C., 1986. Aggregate stability and size distribution. In: Methods of Soil Analysis, Part 1. (Ed.: Klute, A.). $2^{\text {nd }}$ ed. Agron. Monogr. 9. ASA and SSSA, Madison, WI. 425-442.

KENKILÄ, J., 2005. The laser diffraction grain size analysis of late miocene floodplain sediments from lantian, in Shaanxi Province, Northern China. Master's thesis. University of Helsinki. Department of Geology Faculty of Mathematics and Natural Sciences. Helsinki

Kerry, R., Rawlins, B. G., Oliver, M. A. \& LACInSKA, A. M., 2009. Problems with determining the particle size distribution of chalk soil and some of their implications. Geoderma. 152. 324-337.

KONDRLOVA, E., IGAZ, D. \& HORAK, J., 2015. Effect of calculation models on particle size distribution estimated by laser diffraction. The Journal of Ege University Faculty of Agriculture. Special Issue. 21-27.

KONERT, M. \& VANDEnBERGHE, J., 1997. Comparison of laser grain size analysis with pipette and sieve analysis: a solution for the underestimation of the clay fraction. Sedimentology. 44. 523-535.

KowAlEnko, C. G. \& BABUIN, D., 2013. Inherent factors limiting the use of laser diffraction for determining particle size distributions of soil and related samples. Geoderma, 193-194. 22-28.

Kun, Á., KATONA, O., SiPOS, GY. \& BARTA, K., 2013. Comparison of pipette and laser diffraction methods in determining the granulometric content of fluvial sediment samples. Journal of Environmental Geography. 6. 49-54.

Kuráž, V., Frouz, J., Kuráž, M., MaKó, A., Šustr, V., CejPeK, J., Romanov, O. V. \& ABAKumov, V., 2012. Changes in some physical properties of soils in the chronose-quence of self-overgrown dumps of the Sokolov quarry-dump complex, Czechia. Eurasian Soil Sci. 45. (3) 266-272. 
LAMORSKI, K., BIEgAnOwski, A., RYŻAK, M., SOChan, A., SŁawińsKi, C. \& STELMACH, W., 2014. Assessment of the usefulness of particle size distribution measured by laser diffraction for soil water retention modelling. J. Plant Nutr. Soil Sci. 177. 803-813.

LE BISSONNAIS, Y., 1996. Aggregates stability and assessment of soil crustability and erodibility: I. Theory and methodology. Eur. J. Soil Sci. 47. 425-437.

LiU, T. K., Odell, R. T., EtTer, W. C. \& Thornburn, T. H., 1966. Comparison of clay contents determined by hydrometer and pipette methods using reduced major axis analysis. Soil Sci. Soc. Am. Proc. 30. 665-669.

Loizeau, J-L., Arbouille, D., SAntiago, S. \& Vernet J-P., 1994. Evaluation of a wide range laser diffraction grain size analyzer for use with sediments. Sedimentology. 41. 353-361.

Loveland, P. J. \& Whalley, W. R., 1991. Particle size analysis. In: Soil and environmental analysis, physical methods (Eds.: SMITH, K. A. \& Mullins, C. E.). Marcel Dekker Inc. New York. 281-314.

LU, N., Ristow, G. H. \& LiKOS, W. I., 2000. The Accuracy of hydrometer analysis for fine-grained clay particles. Geotech. Test. J. 23. 487-495.

Ma, Z., Merkus, H. G., De Smet J. G. A. E., HefFels, C. \& Scarlett, B., 2000. New developments in particle characterization by laser diffraction: size and shape. Powder Technology. 111. 66-78.

MADARÁSZ, B., JAKAB, G., SzALAI, Z. \& JuHOS, K., 2012. Lézeres szemcseösszetétel elemzés néhány előkészítő eljárásának vizsgálata nagy szervesanyag-tartalmú talajokon. Agrokémia és Talajtan. 61. 381-398.

Makó, A., Herczeg, E., F. Kardos, A., Tóth, J., Hauk, G., RAJKai, K., Hernádi, H., VARGA, T. \& BARNA, GY., 2016a. Methodological experiences of particle size distribution analysis by laser diffraction method. In: $23^{\text {rd }}$ International Poster Day. Bratislava, $10^{\text {th }}$ November 2016. 98-107.

MAKÓ, A. \& HERNÁDI, H., 2010. A talajok szemcseösszetételének vizsgálata során alkalmazott különböző előkészítési módszerek összehasonlító értékelése. In: Mérnökgeológia, kőzetmechanika (Szerk.: TÖRÖK Á. \& VÁSÁRHELYI B.). Müegyetemi Kiadó, Budapest. 101-108.

MaKó, A., MÁTÉ, F., Tóth, M., LÁszló, K. \& NÉMETH, T., 2002. A különböző szabványos módszerek szerint mért agyagtartalom és néhány egyéb talajfizikai paraméter összefüggésének vizsgálata. XVI. Országos Környezetvédelmi Konferencia és Szakkiállítás. Siófok. 2002. szeptember 11-13. 231-239.

MAKÓ, A., RAJKAI, K., HERNÁDI H. \& HAUK G., 2014. Comparison of different settings and pre-treatments in soil particlesize distribution measurement by laserdiffraction method. Agrokémia és Talajtan. 63. 19-28.

MaKó, A., Szabó, J., BAKACsi, Zs., Koós, S., HAuK, G., JANEK, H., RAJKAI, K. \& BARNA, GY., 2016b. Applicability of laser diffraction analyses in soil physics practice. Review on Agriculture and Rural Development. 5. 32-37.

Makó, A., Tóth, B., RAJKAI, K., Szabó, J., BAKACsi, Zs. \& BARnA, Gy., 2016c. Particle size distribution measurements by laser diffraction method in practical soil physics. Abstract book of $11^{\text {th }}$ International Conference on Agrophysics. 26-28 September 2016, Lublin, Poland. 148.

MALVERN OPERATORS GUIDE, 1999. Malvern Press, Malvern, UK. 
Mason, J. A., Greene, R. S. \& JoECKel, R. M., 2011. Laser diffraction analysis of the disintegration of aeolian sedimentary aggregates in water. Catena, 87. 107-118.

MASON, J., KASMERCHAK, C. \& LIANG, M. 2016. Monitoring aggregate disintegration with laser diffraction: A tool for studying soils as sediments. Geophysical Research Abstracts 18. EGU2016-5279.

Matsuyama, T. \& YAmAмото, H., 2004. Particle shape and laser diffraction: a discussion of particle shape problem. J. Disper. Sci. Technol. 25. 1-8.

Matthews, M. D., 1991. The effect of grain shape and density on the size measurement. In: Principles, methods, and applications of particle size analysis (Ed.: SYVITSKI, J. P. M.). Cambridge University Press. Cambridge. 22-33.

McCaVE, I. N., BRyant, R. J., COOK, H. F. \& Coughanowr, C. A., 1986. Evaluation of a laser-diffraction size analyzer for use with natural sediments. Research Methods Papers. 561-564.

MCKeAgue, J. A., 1978. Manual on soil sampling and methods of analysis. $2^{\text {nd }}$ ed. Canadian Society of the Soil Science. Ottawa.

Miller, B. A. \& SCHAetzl, R. J., 2012. Precision of soil particle size analysis using laser diffractometry. Soil Sci. Soc. Am. J. 76. 1719-1727.

Miller, M. P., RAdCliffe, D. E. \& Miller, D. M., 1988. An historical perspective on the theory and practice of soil mechanical analysis. J. Agron. Education. 17. 24 28.

MSZ-08 0205-78, 1979. A talaj fizikai és vízgazdálkodási tulajdonságainak vizsgálata. MÉM, Budapest

Muggler, C. C., PAPe, Th. \& Buurman, P., 1997. Laser grain-size determination in soil genetic studies 2. Clay content, clay formation, and aggregation in some Brazilian Oxisols. Soil Sci. 162. 219-228.

Nemes, A., Wösten, J. H. M., Lilly, A. \& Oude VoshaAR, J. H., 1999. Evaluation of different procedures to interpolate particle-size distributions to achieve compatibility within soil databases. Geoderma. 90. 187-202.

ORZEChowski, M., SMÓlCZYŃSKI, S., DŁugosz, J. \& PożNiAK, P., 2014. Measurements of texture of soils formed from glaciolimnic sediments by areometric method, pipette method and laser diffraction method. Soil Science Annual. 65 (2). 72-79.

ÖZER, M., ORHAN, M. \& IşIK, N., 2010. Effect of particle optical properties on size distribution orf soils obtained by laser diffraction. Environ. Eng. Geosci. 16. 163173.

Pabst, W., Kunes, K., Havrda, J. \& Gregorova, E., 2000. A note on particle size analyses of kaolins and clays. Journal of the European Ceramic Society. 20. 14291437.

PAZ-Ferreiro, J., VÁzQuez, E. V. \& Miranda, J. G. V., 2010. Assessing soil particlesize distribution on experimental plots with similar texture under different management systems using multifractal parameters. Geoderma. 160. 47-56.

Peng, H., Horton, R., LeI, T., DAI, Z. \& WANG, X., 2015. A modified method for estimating fine and coarse fractal dimensions of soil particle size distributions based on laser diffraction analysis. J. Soil Sediment. 15 (4). 937-948.

Pieri, L., BitTelli, M. \& PiSA, P. R., 2006. Laser diffraction, transmission electron microscopy and image analysis to evaluate a bimodal Gaussian model for particle size distribution in soils. Geoderma, 135. 118-132. 
Polakowski, C., RyŻaK, M., Bieganowski, A., Sochan, A., BArtmińsKi, P., DęBICKI, R. \& STELMACH, W., 2015. The reasons for incorrect measurements of the mass fraction ratios of fine and coarse material by laser diffraction. Soil Sci. Soc. Am. J. 79 (1). 30-36.

Polakowski, C., Sochan, A., BIEgAnowski, A., RYŻAK, M., FÖldÉNYI, R. \& Tóth, J. 2014. Influence of the sand particle shape on particle size distribution measured by laser diffraction method. Int. Agrophys. 28 (2). 195-200.

Pye, K. \& BlotT, S. J., 2004. Particle size analysis of sediments, soils and related particulate materials for forensic purposes using laser granulometry. Forensic Sci. Int. 144. 19-27.

RAJKAI, K., 1988. A talaj víztartó képessége és különböző talajtulajdonságok összefüggéseinek vizsgálata. Agrokémia és Talajtan. 36-37. 15-30.

RAJKAI, K., KABOS, S., VAN GENUCHTEN, M. TH. \& JANSSON, P. E., 1996. Estimation of water-retention characteristics from the bulk density and particle-size distribution of Swedish soils. Soil Sci. 161. 832-846.

RAMASWAMY, V.\& RAO, P. S., 2006. Grain size analysis of sediments from the northern Andaman sea: Comparison of laser diffraction and sieve-pipette techniques. Journal of Coastal Research. 22. 1000-1009.

RAWLINS, B. G., WraGG, J. \& LARK, R. M., 2013. Application of a novel method for soil aggregate stability measurement by laser granulometry with sonication. Eur. J. Soil Sci. 64. 92-103.

RoBERSON, S. \& WeltJe, G. J., 2014. Inter-instrument comparison of particle-size analysers. Sedimentology. 61. 1157-1174.

RYŻAK, M. \& BIEGANOWSKI, A., 2010. Determination of particle size distributionof soil using laser diffraction - comparison with areometric method. Int. Agrophys. 24. $177-181$.

RYŻAK, M. \& BIEGANOWSKI, A., 2011. Methodological aspects of determining soil paricle-size distibution using the laser diffraction method. J. Plant Nutr. Soil Sci. 174. 624-633.

RYŻAK, M., WALCZAK, R. T. \& NIEWCZAS, J., 2004. Porównanie rozkładu granulometrycznego cząstek glebowych metodą dyfrakcji laserowej i metodą sedymentacyjną.. Acta Agrophysica. 4. 509-518. (lengyelül)

Schulte, P., LehmKuhl, F., Steininger, F., Loibl, D., LOCKOT, G., Protze, J., FisCHER, P. \& STAUCH, G., 2016. Influence of $\mathrm{HCl}$ pretreatment and organo-mineral complexes on laser diffraction measurement of loess-paleosol-sequences. Catena. 137. 392-405.

Segal, E., Shouse, P. J., Bradford, S. A., Skaggs, T. H. \& Corwin, D. L., 2009. Measuring particle size distribution using laser diffraction: implications for predicting soil hydraulic properties. Soil Sci.174 (12). 639-645.

SERbAN, R. D., SiPOS, GY., PoPESCU, M., URdEA, P., ONACA, A. \& LAdÁNYI, Zs., 2015. Comparative grai-size measurements for validating sampling and pretreatment techniques in terms of solifluction landforms, Southern Carpathians, Romania. Journal of Environmental Geography. 8 (1-2). 39-47.

Shein, E. V., Milanovskit, E. Y. \& Molov, A. Z., 2006. The effect of organic matter on the difference between particle-size distribution data obtained by the sedimentometric and laser diffraction methods. Eurasian Soil Sci. 39. (Suppl. 1) 84-90. 
Shein, E.V., LAZAREV, V. I., Aidiev, A.Yu., SAKunKonchaK, T., KuZnETSOV, M.YA., MilanovskiI, E.Yu. \& KhaIDAPOVA, D. D., 2011. Changes in the physical properties of typical Chernozems of Kursk oblast under the conditions of a longterm stationary experiment. Eurasian Soil Sci. 44. 1097-1103.

SOCHAN, A., BIEGANOWSKI, A. BARTMIŃSKI, P., RYŻAK, M., BRZEZIŃSKA, M., DĘBICKI, R., STUCZYŃSKI, T. \& POLAKOWSKI, C. 2015. Use of the laser diffraction method for assessment of the pipette method. Soil Sci. Soc. Am. J. 79. 37-42.

Sochan, A., Bieganowski, A., RyżAK, M., Dobrowolski, R. \& BARTMiński, P., 2012. Comparison of soil texture determined by two dispersion units of Mastersizer 2000. Int. Agrophys. 26. 99-102.

SOCHAN, A., POLAKOWSKI, C. \& ŁAGÓD, G. 2014. Impact of optical indices on particle size distribution of activated sludge measured by laser diffraction method. Ecol Chem. Eng. S. 21 (1). 137-145.

TAubner, H., Roth, B. \& TIPPKÖTTER, R. 2009. Determination of soil texture: Comparison of the sedimentation method and the laser-diffraction analysis. J. Plant Nutr. Soil Sci. 172. 161-171.

THOMAS, K. A., \& REDSTEER, M. H., 2016. Vegetation of semi-stable rangeland dunes of the Navajo Nation, Southwestern USA. Arid Land Res. Manag. 30. 400-411.

TOMBÁCZ, E., 2002. Adsorption from electrolyte solutions. In: Adsorption: theory, modeling, and analysis (Ed.: TóTH, J.). Marcel Dekker. New York. 711-742.

Tóth, B., Weynants, M., Nemes, A., Makó, A., Bilas, G. \& Tóth, G., 2015. New generation of hydraulic pedotransfer functions for Europe. Eur. J. Soil Sci. 66. 226-238.

Tóth, G., MAKó, A. \& MÁtÉ, F., 2009. Designation of local varieties in the Hungarian soil classification system: Remarks from a viewpoint of land evaluation application. Eurasian Soil Sci. 42. 1448-1453.

Usowicz, B., LIPIEC, J. \& UsowICZ, J. B., 2008. Thermal conductivity in relation to porosity and hardness to terrestrial porous media. Planet. Space Sci., 56. 438-447.

VAN REEUWIJK, L. P., (ED.) 2002. Procedures for soil analysis. Technical Paper $9.6^{\text {th }}$ ed. International Soil Reference and Information Centre. Wageningen. The Netherlands.

VAndeCASTEEle, B. \& DE Vos, B., 2001. Relationship between soil textural fractions determined by sieve-pipette method and laser diffractometry. IBW Br R 5. 1-19.

VÁRALLYAY, GY., 1993. A fizikai talajféleség meghatározása. In: Talaj- és agrokémiai vizsgálati módszerkönyv. 1. A talaj fizikai, vízgazdálkodási és ásványtani vizsgálata (Ed.: BUZÁs, I.). INDA 4231 Kiadó. Budapest. 45-57.

VArga, Gy., Cserháti, Cs., Kovács, J. \& Szalai, Z., 2016. Saharan dust deposition in the Carpathian Basin and its possible effects on interglacial soil formation. Aeolian Research. 22. 1-12.

VDOVIĆ, N., OBHOĐAS̆, J. \& PIKELJ, K., 2010. Revisiting the particle-size distribution of soils: comparison of different methods and sample pre-treatments. Eur. J. Soil Sci. 61. 854-864.

Virto, I., GartZia-BengoetXeA, N. \& FernándeZ-UGalde, O., 2011. Role of organic matter and carbonates in soil aggregation estimated using laser diffractometry. Pedosphere. 21 (5). 566-572.

Walling, D. E., Owens, P. N., Waterfall, B. D., Leeks, G. J. L. \& Wass, P. D., 2000. The particle size characteristics of fluvial suspended sediment in the Humber and Tweed catchments, UK. Sci. Total Environ. 251-252. 205-222. 
WANG, W., LIU, J., ZHAO , B., ZHANG, J., LI, X. \& YAN, Y. 2015. Critical evaluation of particle size distribution models using soil data obtained with a laser diffraction method. PLoS ONE. 10 (4). e0125048.

WAnG, W-P., LiU, J-L., Zhang, J-B., Li, X-P., Cheng, Y-N., XIN, W-W. \& Yan, Y-F. 2013. Evaluation of laser diffraction analysis of particle size distribution of typical soils in China and comparison with the sieve-pipette method. Soil Science. 178. 194-204.

Weaver, J. W., Charbeneau, R. J., Tauxe, J. D., Lien, B. K. \& Provost, J. B., 1994. The hydrocarbon spill screening model (HSSM). 1. US EPA. EPA/600/R-94/039a.

WeINER, B. B., 1984. Particle and droplet sizing using Fraunhofer diffraction. Chem. Anal. 73. 135-172.

WÖsten, J. H. M., PAChePsky, YA. A. \& RaWls, W. J., 2001. Pedotransfer functions: bridging the gap between available basic soil data and missing soil hydraulic characteristics. J. Hydrol. 251. 123-150.

XU, R. \& Di GUIDA, O. A., 2003. Comparison of sizing small particles using different technologies. Powder Technol. 132. 145-153.

YANG, X., ZHANG, Q., LI, X., JIA, X., WEI, X. \& SHAO, M., 2015. Determination of Soil Texture by Laser Diffraction Method. Soil Sci. Soc. Am. J. 76 (6). 1556-1566.

ZoBECK, T. M., 2004. Rapid soil particle size analyses using laser diffraction. Appl. Eng. Agric. 20. 633-639.

\section{Experience gained in the particle size distribution analysis of soil samples us- ing the laser diffraction method}

$$
{ }^{1} \text { A. MAKÓ, }{ }^{1,2} \text { T. VARGA, }{ }^{1,3} \text { H. HERnÁdI, }{ }^{4} \text { V. LABANCZ and }{ }^{1} \text { Gy. BARNA }
$$

${ }^{1}$ Institute for Soil Science and Agricultural Chemistry, Centre for Agricultural Research, Hungarian Academy of Sciences, Budapest

${ }^{2}$ Department of Natural and Environmental Geography, Institute of Geography, Faculty of Sciences, University of Pécs, Pécs

${ }^{3}$ Department of Crop Production and Soil Science, Georgikon Faculty, University of Pannonia, Keszthely

${ }^{4}$ Department of Soil Science and Agricultural Chemistry, Institute of Environmental Sciences, Faculty of Agricultural and Environmental Sciences, Szent István University, Gödöllő

\section{Summary}

Laser diffraction particle size analysis is an up-to-date method for use in soil analysis, but the introduction of a uniform measurement standard (possibly for specific instruments) would greatly increase the reproducibility of the measurements. Preparation methods (disintegration of the cementing agents ensuring the soil structure, dispersion of elementary particles) play an important role in this, but again no uniform standards have yet been compiled. Based on the papers reviewed in the 
present work it can be stated that both the optimum sample preparation method and the best instrument settings depend to a great extent on the physical and chemical properties of the soil to be measured. The suitability of the conversion methods used to compare the results with those obtained using conventional sedimentation methods (fraction size limit conversions, conversion equations) is also dependent on the soil sample and LDM technique. The use of laser diffraction particle size analysis for studying the aggregate stability of soils is a promising methodological option, but standardisation will be essential for the interpretation of the measurements and the achievement of comparability.

Table la-c. References to the use of laser diffraction methods to analyse the particle size distribution of soils, listed according to instrument types and dispersion units. (1) Instrument type. (2) Dispersion unit. (3) Type of sample (number of samples). (4) References. (5) Reference code.

Table 2. Choice of methods for removal of cementing agents and dispersing aggregates in the papers reviewed. (1) Removing of cementing agents. (2) Reference code. (3) Ultrasonication. (4) Chemical dispersing. Notes *: Continuous ultrasonic treatment during measurement; for several of the durations studied, the values recommended by the authors are given in italics in brackets

Table 3. Pumping and stirring speeds set in the dispersion units by various authors. (1) Dispersion unit. (2) Stirring speed (rpm). (3) Pump speed (rpm). (4) Reference code.

Table 4. Obscuration of the soil suspension during the measurements in the papers reviewed. (1) Obscuration (\%). (2) Reference code. Note *Manufacturer's recommendation (MALVERN OPERATORS GUIDE, 1999)

Table 5. Choice of optical model in the papers reviewed. (1) Optical model. (2) Reference code.

Table 6. Choice of optical parameters in the papers reviewed. (1) Absorption index. (2) Reference code. (3) Refractive index.

Table 7. References to aggregate stability measurements using laser diffraction techniques, listed according to instruments types and dispersion units. (1) Instrument type. (2) Dispersion unit. (3) Type of sample (number of samples). (4) References.

Key words: laser diffraction, particle size distribution, aggregate stability, conversion options, standardization of methods in soil physics 